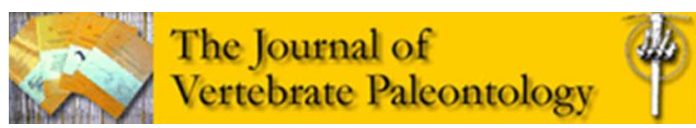

\title{
A new osteostracan fauna from the Devonian of the Welsh- Borderlands and observations on the taxonomy and growth of Osteostraci
}

\begin{tabular}{|r|l|}
\hline Journal: & Journal of Vertebrate Paleontology \\
\hline Manuscript ID: & Draft \\
\hline Danuscript Type: & Article \\
\hline Complete List of Authors: & $\begin{array}{l}\text { Keating, Joseph } \\
\text { Sansom, Robert; University of Bath, Department of Biology and } \\
\text { Biochemistry } \\
\text { Purnell, Mark; University of Leicester, Department of Geology }\end{array}$ \\
\hline Key Words: & Osteostraci, Taxonomy, Devonian, Growth \\
\hline \multicolumn{2}{|c}{} \\
\hline
\end{tabular}

SCHOLARONE ${ }^{m}$

Manuscripts 
A new osteostracan fauna from the Devonian of the Welsh-Borderlands and observations on the taxonomy and growth of Osteostraci

\author{
JOSEPH N. KEATING, ${ }^{1, \dagger}$ ROBERT S. SANSOM, ${ }^{*}, 1,2$ and MARK A. PURNELL ${ }^{1}$ \\ ${ }^{1}$ Department of Geology, University of Leicester, Leicester, LE1 7RH, United Kingdom; \\ ${ }^{2}$ Department of Biology and Biochemistry, University of Bath, Claverton Down, Bath, BA2 \\ 7AY, United Kingdom, r.sansom@ bath.ac.uk \\ ${ }^{\dagger}$ Current Address: 11 Park Way Close, Southwick, West Sussex, BN42 4LE, United \\ Kingdom, joe_keating@live.co.uk \\ RH: KEATING AND SANSOM-DEVONIAN OSTEOSTRACANS
}

*Corresponding author 


\begin{abstract}
The Osteostraci are a morphologically diverse group of jawless fishes considered as sister-taxon to jawed vertebrates. Fossil Osteostraci therefore have wide reaching ramifications for our understanding of the origin and evolution of gnathostomes. Their utility in this context is currently impeded by rudimentary taxonomy of faunas from the United Kingdom. Principal among these is a well-preserved, previously undescribed fauna from the Early Devonian (Lochkovian) of Wayne Herbert Quarry, Herefordshire. Here we provide a description of new osteostracan material from this fauna. Anatomical observations of the character rich, taxonomically informative headshield, combined with quantitative measurements, has permitted identification of 15 variable characters. From these, 7 discrete morphogroups are recognised and used to establish the taxonomy of the material. This includes two new species of Zenaspididae (Zenaspis waynensis and Diademaspis janvieri), two new species of Cornuata incertae sedis (Janaspis newtonensis and J. punctata), two indeterminate species and Pattenaspis whitei Stensiö, 1932, which is redescribed on the basis of new material. Our analyses indicate that cornuate osteostracan species are likely over-split due erection of new taxa based on poorly preserved type specimens, inadequate consideration of taphonomic character loss, and over reliance on continuous rather than discrete characters. Furthermore, patterns of dermoskeleton ornamentation and tessellation of Diademaspis janvieri and Cornuata indet. gen. sp. B are used to infer mechanisms of dermoskeletal growth. These new data allow incorporation of this fauna into scenarios of osteostracan evolution, considerations of gnathostome origin and studies of global Lochkovian diversity.
\end{abstract}




\section{INTRODUCTION}

Much of the morphological gulf that separates extant jawless from jawed fish was once filled by the diverse jawless fishes now known only as fossils from Palaeozoic deposits from around the world. These fossil 'ostracoderms' are therefore of fundamental importance for helping us to reconstruct the origin and early evolution of gnathostomes- one of the most significant evolutionary events in vertebrate history. A group of central importance in this context is the Osteostraci. The Osteostraci are the sister group to all jawed vertebrates (Forey and Janvier 1993, Janvier 1996, Donoghue et al. 2000), and the two clades share a suite of characters including the presence of pectoral appendages and cellular bone (Sansom 2009a). Consequently, robust understanding of osteostracan palaeobiology is a prerequisite when considering the evolutionary transition through which jaws and other gnathostome characters developed. Detailed studies of the anatomy of the Osteostraci (Janvier 1981, 1985a) and phylogenetic analysis of intra-relationships of the group (Sansom 2008, 2009a, 2009b) allow reconstruction of scenarios of osteostracan and stem-gnathostome evolution. But further resolution of the phylogeny, palaebiogeography and diversity of osteostracans is limited by the currently rudimentary taxonomic state of the British osteostracan faunas from the Welsh Borderlands. Many species erected during the $19^{\text {th }}$ and early $20^{\text {th }}$ century have been diagnosed with reference to character deficient holotype material while other subsequently discovered, well preserved, character-rich material, remains undescribed. Principal among these is the osteostracan fauna from the Lower Devonian of the Wayne Herbert Quarry, near Newton, Herefordshire, where vertebrates (also including acanthodians and heterostracans) have been preserved in fine detail (e.g. White, 1935; Miles, 1973; Dineley, 1999; Brazeau, 2009). Here we present a rigorous anatomical study of these well-preserved specimens, permitting robust taxonomic analysis and allowing us to determine the relevance of this fauna to our understanding of osteostracan evolution and Lochkovian global vertebrate diversity.

\section{MATERIAL AND GEOLOGICAL SETTING}

The specimens described here (listed in supplementary data) are housed at the Natural History Museum, London (NHM). They were recovered from a restricted lens of grey-green siltstone, 66m above the Bishop's Frome Limestone member in the Ditton Group sediments at the Wayne Herbert Quarry (White, 1932, 1935; Allen \& Tarlo, 1963; Dineley, 1999). The lens is within the Rhinopteraspis crouchi zone (White, 1935) consistent with a Lochkovian 
age. The osteostracan bearing lens has also yielded the Turinia pagei thelodont assemblage, heterostracans including Errivaspis waynensis and 'acanthodian' grade vertebrates including Ptomacanthus anglicus (White, 1935a; Miles, 1973; White and Toombs, 1983; Blieck, 1984; Dineley, 1999). Sedimentological analysis (Allen and Tarlo, 1963) and isotopic data of vertebrate remains (Schmitz et al., 1991) indicate a fluvial, freshwater environment (see Dineley, 1999 for details). Prior to our study, the osteostracan material had been prepared using dilute $\mathrm{HCl}$ to remove the crushed bone which masked the fine detail of the specimens, leaving high fidelity impressions of internal and external surfaces (White, 1935a).

\section{METHODS}

In order to take full account of variation and to accurately describe the fauna without unnecessary taxonomic splitting, we have employed a step-wise approach involving 1) description of morphological variation (qualitative and quantitative) of specimens, 2) identification of distinct morphogroups, and 3) comparison of identified morphogroups with previously described fauna to establish taxonomy. For the first stage, the taxonomically informative headshield of each specimen was photographed and anatomical line drawings were produced (Macromedia Freehand) by combining tracing with observations under binocular microscope. Ten quantitative measurements (Fig. 1) were taken for each headshield (obtained from digital photographs using ImageJ image analysis software) and 15 qualitative anatomical characters were described for each (Supplementary data). Specimens sharing a common and unique suite of characters were then placed into distinct morphogroups (Appendix1). These morphogroups were subsequently compared with established species described from Great Britain, Podolia and Spitsbergen. New species are erected for morphogroups that are constrained by a number of discrete characters and found to differ from comparable taxa. Distinctive morphogroups identified from incomplete material however, are retained in open nomenclature following Bengston (1988) and described appropriately. Synonymy lists are annotated following Matthews (1973).

\section{SYSTEMATIC PALEONTOLOGY}

Class OSTEOSTRACI Lankester, 1868

Subclass CORNUATA Janvier, 1981

Order ZENASPIDIDA Stensiö, 1958 
Family ZENASPIDIDAE Stensiö, 1958

ZENASPIS Lankester, 1870

\section{Type species-Zenaspis salweyi Egerton, 1857.}

Emended diagnosis-Modified from Voichyshyn (2006, 2011): Zenaspididae with a midline headshield length of $80-130 \mathrm{~mm}$, equating to at least $60 \%$ of the maximum shield width. Hypophysial division of nasohypophysial opening is expanded relative to the nasal division. Orbital openings are small in proportion to the headshield and bear circumorbital raised rims. Median field is broad. Lateral fields broaden towards the posterior terminus and extend over $0-15 \%$ of the cornual processes. Abdominal division bears a dorsal median ridge. Tesserae of the shield are strikingly small in proportion to the shield size and exhibit single broad central tubercles or granular ornamentation.

Species included-Zenaspis metopias Wängsjö, 1952; Zenaspis podolica Balabai, 1962; Zenaspis major Balabai, 1962; Zenaspis dzieduszyckii Voichyshyn, 2006; Zenaspis kasmyri Voichyshyn 2011. The new species described below, Zenaspis waynensis sp. nov. is provisionally assigned to this genus.

\section{ZENASPIS WAYNENSIS sp. nov.}

(Figs 2,7)

\section{Etymology-From Wayne-Herbert Quarry.}

Diagnosis-Zenaspid with a midline headshield length approximately $92-95 \%$ of the maximum shield width measured just below the level of the pectoral sinuses. Median field short and broad, tapering anteriorly; orbits and median field enclosed within a raised rim; lateral fields narrow yet broad towards their posterior terminus, extending over approximately $15 \%$ of the cornual processes; robust cornua projecting posteriorly and constituting approximately $33 \%$ of maximum headshield length; pectoral sinuses narrow and deep; tesserae ornamented with closely set minute tubercles producing a granular texture; ventral rim ornamented with elongate tubercles surrounded by pitted borders, increasing in size proximodistally and arranged in up to 10 rows slightly discordant with the margin of the headshield.

Material-NHM P24939-40 (holotype, fig. 2A,C), P23832-3 (fig. 2B) and P24945-6.

Description-The headshield of the holotype is $96 \mathrm{~mm}$ long (to cornua tips) and 90mm wide while that of P23832/33 is a slightly larger and P24945/46 slightly smaller. The 
prepineal division of the headshield of Z. waynensis is long, constituting approximately 49 $51 \%$ of the midline headshield length, and broad anteriorly. Lateral fields (preserved only on the holotype and P23832/33) are narrow, broadening posteriorly and extending only a short distance over the cornual processes. The median field is conspicuously broad and short (width $61-65 \%$ of its length), narrowing anteriorly towards the pineal plate. The nasohypophysial opening lies within a narrow and elongate circumnasal depression. The hypophysial division is larger than the nasal division. The orbital openings are circular and fairly small in proportion to the headshield. Both orbits and median field are enclosed within a raised rim. The pectoral sinuses are deep and narrow, bordered by a very robust posteriorly projected cornual processes measuring $30-32 \mathrm{~mm}$ in length. The abdominal division constitutes approximately $14-21 \%$ of the shield length in midline and bears a low dorsal median ridge. A large, dorsoventrally flattened portion of the body is preserved in the holotype, consisting of 33 scale rows.

The headshield is composed of very small tesserae which are convex in profile and exhibit a granular texture produced by minute and closely set tubercles. This granular texture is also seen on the scale rows of the body. The ventral rim of the headshield is ornamented with elongate tubercles which increase in size proximodistally, each encircled within a pitted margin. These occur in rows which do not precisely follow the margin of the headshield, rather diverging from it anteriorly. Similar ornamentation, comprising of elongate tubercles surrounded by pitted margins, exists on the raised rim enclosing the orbits and median field.

Remarks-This species is in many respects comparable to species of the genus Zenaspis: the headshield exhibits a broad anterior, an expanded hypophysial division, small orbits, a broad median field, and poster widening of the lateral fields (the latter character is diagnostic of the Zenaspididae (Janvier 1985a; Sansom 2009a). Another potentially informative character shared between this species and all other Zenaspis species is that the tesserae of the headshield are conspicuously small in proportion to the size of the shield (Stensiö, 1932; Wängsjö, 1952; Janvier, 1985b; Voichyshyn, 2006). This condition appears unique to the genus Zenaspis within the Osteostraci of Great Britain (Stensiö, 1932).

Zenaspis waynensis can be accommodated within Janvier's (1985b) diagnosis of Zenaspis but differs from Voichyshyn's $(2006,2011)$ generic concept in its greater midline headshield length/width ratio and different headshield tessera ornamentation. Shield morphology is similar to the type species of the genus, Zenaspis salweyi Egerton, 1857. Its size corresponds with the smaller specimens of $Z$. salweyi, and both demonstrate very small, circular orbits and long cornual processes constituting around one third the maximum 
headshield length. Z. waynensis differs from Z. salweyi however, in the general outline of the headshield, which is comparatively narrower and longer, with a relatively longer prepineal division. It can also be distinguished by its broad and robust cornual processes, its narrow pectoral sinuses and the shape of its median field. Furthermore the tesserae of $Z$. salweyi are ornamented by few large tubercles unlike the granular texture of $Z$. waynensis. The species compares less closely with Z. metopias Wängsjö, 1952 and Z. dzieduszyckii Voichyshyn, 2006 which exhibit broader and shorter headshields bearing short and thin cornua. The headshield of Z. podolica Balabai, 1962 is similar to Z. waynensis in being narrow with a fairly long prepineal section and robust cornual processes, but it differs in having broad pectoral sinuses (more akin to those of $Z$. salweyi) and ornamentation consisting of single large tubercles (Janvier 1985b). Z. kasmyri Voichyshyn, 2011 also exhibits a fairly narrow shield with narrow pectoral sinuses much as in Z. waynensis, but the former species is easily distinguished by its proportionally larger and much more robust cornual processes. Z. kasmyri also has a proportionally shorter pre-pineal division.

Comparisons with Zenaspis major Balabai, 1962 are limited by the poor preservation of the material referred to this species, but the shield outline is similar to that of $Z$. waynensis, particularly the cornual processes which are similar in their robustness and their proportions relative to the shield. Z. major is, however, much larger than Z. waynensis, and the extension of its lateral fields onto the cornual processes is less pronounced. Z. waynensis is clearly sufficiently distinct from all other cornuate Osteostraci to warrant erection of a new species, but because of the differences between this species and species assigned to the genus Zenaspis, the generic assignment remains open to debate. As we note below in discussion of Cephalaspis, a genus level review of cornuate Osteostraci is rather overdue. The disparities between Z. waynensis and Zenaspis species may be sufficient to merit erection of a new genus, but the broader taxonomic revisions required are beyond the scope of this study.

\section{DIADEMASPIS Janvier, 1985a}

\section{Type species-Diademaspis poplinae Janvier 1985a}

Emended diagnosis-Modified from Voichyshyn (2006, 2011): Zenaspididae attaining a midline headshield length of $90-250 \mathrm{~mm}$ constituting over $90 \%$ of the maximum width. Expanded hypophysial division of nasohypophysial opening relative to the nasal division; pineal plate reduced or absent; small orbits with broad circumorbital raised rims; short and broad median fields; lateral fields narrow anteriorly, broadening significantly 
towards their posterior terminus and extending slightly onto the cornual processes; abdominal division bears a dorsal median ridge; ornamentation of small tubercles surrounding 1 or more central large rounded tubercles.

Species included-D. jarviki Wängsjö, 1952; D. species 1 - D. species 4 of Janvier, 1985a; D. stensioei Afanassieva, 1989; D. sp. Voichyshyn 2006; D. janvieri sp. nov.

Remarks-The problematic species D.? mackenziensis Adrain \& Wilson, 1994, from the southern MacKenzie Mountains, N.W.T., Canada, differs from all other species assigned to Diademaspis in its small size, proportionally large orbits, shape of the dorsal field and style of ornamentation. Consequently we concur with Voichyshyn $(2006,2011)$ that no reason exists to allocate this species within the genus Diademaspis.

DIADEMASPIS JANVIERI sp. nov.

(Figs 3, 7)

Etymology-In honour of Dr Philippe Janvier.

Holotype-P24941/2 (Fig. 3C,D).

Diagnosis-Diademaspis with a prepineal length constituting approximately $50 \%$ of the shield length in midline. Diamond shaped expanded hypophysial division of nasohypophysial opening; wide median field (60\% of length) with a linear posterior margin; lateral fields extend over less than $10 \%$ of the cornual processes; long cornual processes constituting approximately $37 \%$ of the maximum shield length; tesserae of exhibit 1-7 large tubercles forming a central island surrounded by 2-3 rows of smaller tubercles; ventral rim ornamented with irregular rows of elongate tubercles approximately following the shield margin.

Material-NHM P24941-2 (holotype, Fig. 3C,D), P16602-3 (Fig. 3B), P20004a-b, P20005a-b (Fig. 3A), P53026.

Description-All material attributed to this species is somewhat fragmentary in nature. Reconstructing the headshield indicates that the maximum length was likely to have exceeded $120 \mathrm{~mm}$ (90-95mm in midline) with maximum width of $100-110 \mathrm{~mm}$ just posterior to the level of the pectoral sinus. The prepineal division of the shield is long, constituting approximately $50 \%$ of the shield length. The lateral fields $(73-80 \mathrm{~mm}$ long) are narrow anteriorly, gradually broadening towards their posterior terminus. They attain a maximum width at the level with the pectoral sinus, extending slightly less than $10 \%$ over of the cornual processes. The median field is tapered anteriorly producing a tear drop shaped outline with a 
linear posterior terminus; it attains a length around $23 \mathrm{~mm}$ with a maximum width of approximately $12 \mathrm{~mm}$. The circumnasal depression is broad and shallow containing a nasohypophysial opening of which the diamond shaped hypophysial division is appreciably larger than the nasal division. The pineal plate is not directly observed in any specimen yet a weakly defined pineal depression can be seen in specimens P16603 and P24941. The orbits are fairly small in proportion to the shield size, and enclosed within broad circum-orbital raised rims. The pectoral sinuses are fairly broad and deep. The posteriorly projected cornual processes are robust and very long, measuring $45.5 \mathrm{~mm}$ in the holotype, constituting $37 \%$ of its estimated maximum shield length. The exterior margins of the cornual processes curve posteriorly towards the midline. The abdominal division is fairly long, constituting approximately $20-27 \%$ of the shield length in midline. Specimen P20005a/b (Fig. 3A) exhibits a well preserved paddle shaped pectoral appendage measuring $36 \mathrm{~mm}$ in length. Tesserae of the headshield are ornamented with $1-7$ large central tubercles which are rounded anteriorly but become elongate posterolaterally, their axis of elongation following the margin of the shield. Each central 'island' of tubercles is surrounded by $2-3$ rows of significantly smaller tubercles. The ventral rim is ornamented with up to 8 irregular rows of elongate tubercles broadly following the margin of the headshield. The pectoral appendages and scale rows of the body exhibit ornamentation of small closely set tubercles. These appear rounded on the pectoral appendages but are anteroposteriolly elongated on the scale rows.

Remarks-This species can be confidently assigned to the genus Diademaspis because it exhibits a suite of characters diagnostic for this genus (Janvier, 1985a; Voichyshyn, 2006,). It shares with Diademaspis jarvicki Wängsjö, 1952 long cornual processes constituting over a third of the maximum shield length, a short and broad median field and lateral fields that broaden posteriorly, extending only slightly onto the cornual processes. $D$. jarvicki is, however, distinct from $D$. janvieri in the outline of its headshield (which is significantly broader), the shape of its median field (which is approximately rectangular and does not taper anteriorly), and the condition of its tesserae (which are smaller in proportion to the size of the shield and ornamented with tubercles which do not form central islands) (Janvier, 1985a). The occurrence of central 'islands' of large rounded tubercles is a character D. janvieri shares with D. poplinae Janvier 1985a, as well as Diademaspis sp. 1 and sp. 2 of Janvier (1985a). D. poplinae differs from D. janvieri by its comparatively broader shield with proportionally shorter cornual processes, lateral fields which are broader anteriorly and a median field that is roughly rectangular in shape. Comparison with D. stensioei Afanassieva, 1989 is difficult due to the incomplete and 
compressed nature of the latter material. It appears distinct from Diademaspis janvieri, however, in that its pre-pineal division in proportionately shorter. The fragmentary shield of Diademaspis sp. 1 greatly exceeds the size range of $D$. janvieri and bears proportionally smaller cornual processes (Wängsjö, 1952; Janvier, 1985a). Diademaspis sp. 2 can be easily distinguished by the conspicuous grooves of its lateral line system which are bounded by 3-4 rows of tubercles (Janvier, 1985a). The fragmentary shield of Diademaspis sp. 3 exhibits a median field which is tapered anteriorly much as in $D$. janvieri, yet differs in its bilobate posterior terminus (Janvier, 1985a). The incomplete Diademaspis sp. described by Voichyshyn (2006) exhibits a similar tapered median field with a bilobate posterior terminus, thus distinguishing it from D. janvieri. Diademaspis sp. 4 differs in its shield outline and ornamentation (Janvier, 1985a). D. janvieri can clearly be distinguished from all species previously attributed to Diademaspis, thus meriting erection of a new species. Diademaspis is previously known from Spitsbergen (Wängsjö, 1952) and Podolia (Janvier, 1985a, 1985b; Voichyshyn, 2006, 2011), this is therefore a new record of this genus in Great Britain.

\section{Order INCERTAE SEDIS \\ JANASPIS gen. nov.}

Type species_Janaspis pagei Lankester, 1870.

Etymology-After Janus, the Roman god of transitions (a reference to the currently transitional state of osteostracan taxonomy) who also gives his name to the month of January, and subsequently, Dr. P. Janvier.

Diagnosis-Cornuate osteostracan of small size (maximum headshield length or width $60 \mathrm{~mm}$ ) with rounded headshield of approximately equally width and length; maximum headshield width at tips of cornua; median dorsal spinal process; stout cornua of medium length which can possess posteriorly directed spiney tubercles on medial margin; Posterior half of lateral field adjacent to headshield lateral margin, extending onto cornual process whilst anterior half of lateral field extends more medially, leaving a gap between lateral margin of field and lateral margin of headshield.

Species included-Janaspis pagei Lankester, 1870; J. newtonensis sp. nov., J. punctata sp. nov. and potentially "Cephalaspis” powrei Lankester 1870, and "Cephalaspis” watsoni Stensiö, 1932.

Remarks- “Cephalaspis" pagei has been recognised as distinct from the genus Cephalaspis for some time (Janvier, 1985a: p.134). Description here of new material from the 
Wayne Herbert Quarry here reveals similarities between " $C$." pagei and two new species, especially that of the lateral field shape. These similarities warrant the erection of a new genus, Janaspis. “Cephalaspis” powriei Lankester, 1870, has been considered as close to Janaspis pagei (Stensiö, 1932; Janvier, 1985a) but “ C." powrei has shorter, wider, cornua and it is not clear if it possesses the lateral field shape characteristic of Janaspis.

Furthermore, "Cephalaspis” watsoni Stensiö, 1932 exhibits some general similarities with the species of Janaspis but has more distinct curvature of the cornual processes. The precise species composition and morphological variation of the proposed genus will therefore require further examination.

\section{JANASPIS NEWTONENSIS sp. nov.}

(Fig. 4A,B)

Etymology_-For the village of Newton, Herefordshire

Diagnosis - Cornuate osteostracan with a midline headshield length approximately $82-87 \%$ of the maximum shield width, measured at the tips of the cornual processes. Orbits bear circum-orbital raised rims; long and thin median field (width $36 \%$ of length) with parallel straight margins; lateral fields taper anteriorly and extend over approximately $26 \%$ of the cornual processes; robust cornual processes constituting approximately $34 \%$ of the maximum headshield length; long abdominal division tapering posteriorly, terminating slightly before the tips of the cornual process; prominent dorsal median spine; granular texture on tesserae of headshield with single broad flat tubercle in centre; ornamentation of ventral rim comprising up to 13 distinct parallel rows of tiny pits.

Material-The holotype only, P17488-9 (Fig. 4A,B).

Description-The headshield of the holotype is $53 \mathrm{~mm}$ long (to cornua tips, $50 \mathrm{~mm}$ in midline) and 55mm wide although the left portion of the shield is slightly laterally compressed meaning the maximum width of the shield may have been greater. The shield is broadly triangular in shape, narrowing conspicuously towards rostral margin. The prepineal distance is $21 \mathrm{~mm}$ ( $42 \%$ of the midline headshield length). The lateral fields (36mm long) are fairly narrow anteriorly, broadening gradually towards the posterior and extending only a short distance onto the cornual processes, terminating with slightly pointed margins. The median field is broad and fairly long ( $4 \mathrm{~mm}$ x $12 \mathrm{~mm}$ respectively); its margins are broadly straight and parallel to the effect that the width of the median field remains consistent throughout its entire length. The nasohypophysial opening is fairly diminutive and lies within 
a shallowly depressed and weekly defined circumnasal depression. The hypophysial division is diamond shaped and larger than the nasal division. The orbital openings are fairly large and possess thin circumorbital raised rims. A short and narrow pineal plate exists between the orbits. The pectoral sinuses are fairly broad and deep. The robust cornual processes are $18 \mathrm{~mm}$ long and directed posterolaterally. The abdominal division, measured from the level of the pectoral sinus, is $17 \mathrm{~mm}$ constituting approximately $33 \%$ of the headshield midline length. The tesserae of the headshield grade into the scale rows of the body, with the effect that the posterior margin of the abdominal division is difficult to discern accurately. The abdominal division bears a prominent dorsal median spine, however its shape and dimensions cannot be accurately determined (the specimen is too fragile to permit a plaster moulding). The pectoral appendages have patchy preservation; the right appendage being the most complete. Its length is estimated to be $18.5 \mathrm{~mm}$. The pectoral appendage exhibits a paddle-like morphology which is regarded as a generalised character of cornuate Osteostraci (Coates, 2003; Janvier et al., 2004; Sansom et al., 2008; Sansom 2009a).

The headshield shield is composed of fairly small tesserae, each ornamented with a single broad low relief central tubercle. This is overprinted by minute and closely set tubercles, producing a granular external texture. The ventral rim of the headshield, preserved as an external mould on the counterpart (p17489). It is ornamented with conspicuous parallel rows of tubercles which follow the margin of the shield. The rim is broadest at the rostral margin, where up to 13 rows of pits are discernable. The pectoral appendage is formed of tesserae much smaller than those of the headshield. The ornamentation comprises closely set tubercles, similar to those of the headshield tesserae, yet lacking broad central tubercles. The scale rows of the body are ornamented with a similar granular texture.

Remarks-The species compares most strikingly with Janaspis pagei Lankester, 1870. The shield falls within the size range of this species, as identified by Stensiö (1932) and shares a similar shield profile, with maximum width occurring towards the tips of posterolaterally projected cornual processes, narrowing significantly towards the rostral margin. The shape of the lateral fields and nasohypophysial opening, as well as the presence of a dorsal median spine, are all consistent with Stensiö's (1932) redescription of the species. Janaspis newtonensis differs however in the shape of its median field, which is broader, shorter and does not narrow anteriorly. Furthermore, its ornament differs from the condition observed in J. pagei i.e. small, rather widely spaced and well developed tubercles surrounding 1-2 larger central tubercles. It also lacks posteriorly projected spiny tubercles on the interior margin of the cornual processes. This character, however, could well reflect 
differences in preservation or preparation (i.e. splitting through different rock layers). Because of this difficulty, absence/presence of tubercles on the interior margins of the cornual processes cannot confidently be used to distinguish between species. The ventral rim of $J$. newtonensis is ornamented similarly to that of C. cradleyensis Stensiö, 1932 (White and Toombs, 1983), but its shield morphology is quite different. J. newtonensis is distinguished from $C$. cradleyensis by the ornamentation of its dorsal headshield tesserae, as well as its relatively broader shield, shorter prepineal divison, and shorter cornual processes. The headshield of $J$. newtonensis therefore differs significantly from previously described cornuate Osteostraci to merit the erection of a new species, which falls within the variation of the newly identified genus Janaspis.

\section{JANASPIS PUNCTATA sp. nov.}

\section{(Figs 5A-F, 7)}

Etymology_Latin; meaning 'dotted', in reference to the ornamentation of the headshield.

Diagnosis - Cornuate osteostracan with a midline headshield length approximately $70-76 \%$ of maximum width which occurs approximately mid length of the cornual processes. Median field narrow anteriorly, broadening posteriorly with maximum width approximately $40 \%$ of length; thin circumorbital raised rims ornamented with up to 3 rows of minute tubercles; broad lateral fields extending over $20 \%$ of the cornual processes; cornual processes constituting approximately $32-40 \%$ of the maximum shield length; tesserae of the headshield exhibit granular texture of minute, closely set tubercles which overprints 7-10 large obtuse and evenly spaced tubercles; ventral rim demonstrates up to 13 irregular rows of pits which approximately follow the margin of the shield.

Material-NHM P24920-1 (holotype, fig. 5B), P16604-5, P16606-7 (Fig. 5C), P16608, P20004a (Fig. 5A), P20004c, P24920/21 (Fig. 5E,F), P24926-7, P24924-5 (Fig. 5B), P24929-30, P24935-6 (Fig. 5D), P53027a-b.

Description-The headshield ranges from 44-54mm long (to level of cornua tips, 37$42 \mathrm{~mm}$ midline headshield length only) with maximum width of $54-57 \mathrm{~mm}$ in the region of the cornua. The prepineal division is rather short, constituting approximately $42-45 \%$ of the shield length in midline. The lateral fields are broad $(27-34 \mathrm{~mm})$ and extend over the cornual processes. The median field (13-15mm long, 5-6mm maximum width) is narrow anteriorly. The median field of P24920/21 is bottle-shaped and preserves the external openings of the 
endolymphatic ducts at the postero-lateral margins. The nasohypophysial is within a narrow and shallowly circumnasal depression which exhibits a pointed anterior margin. The hypophysial division appears to be expanded relative to the nasal division. The orbital openings are fairly large relative to the headshield and are enclosed within narrow circumorbital raised rims (Fig. 5D). They are connected via a thin and short pineal plate. The slender cornual processes project posteriorly and attain a length of $14-23 \mathrm{~mm}$, constituting 32$40 \%$ of the maximum shield length. The abdominal division (9-11 mm long) constitutes roughly $25 \%$ of the shield length in midline and does not appear to bear a dorsal median ridge. NHM P16606 preserves as an external mould the right pectoral appendage which is incomplete and composed of discrete rows of very small tesserae. Impressions of the ventral surface of the shield, preserved in specimens P20004a (i) and P24935, suggest at least 8 external branchial openings were present. Specimen P24924/25 (i) (Fig. 5B) exhibits an almost complete articulated body, compressed laterally, bearing a single posterior dorsal fin posterior of approximately 20 scale rows.

The headshield ornamentation is preserved on all specimens and consists of evenly spaced, large obtuse tubercles which themselves are overprinted by minute and closely set tubercles which produce a granular texture. The tesserae of the shield can only be discriminated in the lateral and median fields of specimen P24921. They are small in proportion to the shield size and each ornamented with 7-10 obtuse tubercles. The ventral rim is ornamented with up to 13 irregular rows of small pits which approximately follow the margin of the headshield. The circumorbital raised rims of specimen P24920 are ornamented with up to 3 rows of minute tubercles. The tubercles of the body scales are closely set and elongated anteroposteriorly.

Remarks-The species also compares closely with Janaspis pagei Lankester, 1870. Again, the headshields fall within the known size range of this species (Stensiö, 1932) and shares characters including large orbital openings in proportion to the headshield size, a median field which is narrow anteriorly, lateral fields that are broad and extend considerably over the cornual processes and a similar style of ornamentation consisting of minute tubercles producing a granular texture which overprints a single obtuse central tubercle (rather than several evenly spaced obtuse tubercles). Janaspis pagei can be distinguished from the morphogroup described here, however, by its proportionally shorter cornual processes, which bear conspicuous spiny tubercles on their interior margins, and by its prominent dorsal median spine. Perhaps a closer comparison can be drawn with 'Cephalaspis' watsoni Stensiö, 1932 which possesses broad lateral fields that extend considerably over long cornual 
processes, a median field that is bottle-shaped and a style of ornamentation identical to that of the Wayne Herbert specimens. ' $C$ '. watsoni may be distinguished, however, by its more strongly medially curved cornual processes and by the dorsal median ridge of its abdominal division. It is possible that discovery of more material will reveal that ' $C$ '. watsoni and Janaspis punctata are part of a single, variable species, but this is currently speculative. The lack of a dorsal median ridge may be a taphonomic artefact as all specimens exhibit compression to some degree. Furthermore, ' $C$ '. watsoni exhibits variability with regards to the curvature of the cornual processes (NHM P16157 has incomplete cornua but they are nevertheless weakly curved in comparison to the holotype). Given the data presently available however, it is preferable to acknowledge Janaspis punctata as a new species.

\section{PATTENASPIS Stensio 1958}

\section{Type species-Pattenaspis acuminata Wängsjö, 1952.}

Emended diagnosis-Modified from Stensiö (1958), Janvier (1985a) and Voichyshyn (2011): Small to medium sized cornuate osteostracan with long, fine, medially curved cornua; narrow headshield with accentuated rostral point and short abdominal division with low dorsal ridge; narrow lateral fields; well developed pineal plate; oval shaped oralobranchial fenestra.

Species included- $P$. acuminata Wängsjö, 1952; $P$. artensis Blieck and Janvier, 1989; P. bardenheuri Friman, 1986; P. divaricata Wängsjö, 1952; P. deltoides Wängsjö, 1952; P. eukeraspidoides Stensiö, 1927; P. eurhynchus Wängsjö, 1952; P. foeyni Wängsjö, 1952; P. heintzi Stensiö, 1927; P. oreas Wängsjö, 1952; P. pygmaea Wängsjö, 1952; P. rogalai Balabai, 1962; P. watneliei Stensiö, 1927; P. woschmidti Friman, 1986.

Remarks-Pattenaspis was initially erected by Stensiö (1958) although under fairly loose criteria describing principally ventral or internal features which make it difficult to make meaningful comparisons with other species. Although initially described by Stensiö (1958) as " $<$ Cephalaspis $>$ species du type whitei" we follow Janvier (1985) in considering $P$. acuminata as type species.

PATTENASPIS WHITEI Stensiö, 1932

(Figs 4C-E, 7) 
[?P] Cephalaspis lyelli Woodward, 1891: 179-181

[?P] Cephalaspis salweyi Woodward, 1891: 181-182

[?] Cephalaspis sp. Patten, 1903: 844, pl. 1, fig. 4

[v] Cephalaspis whitei Stensiö, 1932: 93-96, figs. 9, 3B, 30, Pl. 18; figs. 3-6, Pl. 19; figs. 1-2, Pl. 20; fig. 3, Pl. 21, Pl. 27; fig. 5, Pl. 32; fig. 6, Pl. 61, 62.

[vP] Cephalaspis jacki White, 1932.

Emended diagnosis-Cornuate osteostracan with a midline headshield length approximately $67-78 \%$ of the maximum shield width. Prepineal division approximately 47$48 \%$ of midline shield length; narrow circum-orbital raised rims; median field long and broad with an elongate octagonal outline, width $40-59 \%$ of length; lateral fields fairly broad, extending over $25-28 \%$ of the cornual processes, terminating with pointed posterior margins; cornual processes long (approximately $37-41 \%$ of maximum headshield length) with spiny tubercles on interior margin; abdominal division fairly short with low dorsal median ridge; tesserae of the headshield ornamented with approximately 7-10 large rounded tubercles which are evenly spaced and surround a similar sized or slightly larger central tubercle.

Material- P16310 (Fig. 4E) and P19198/9 (Fig. 4C,D), in addition to the holotype (NHM P5048) and 20 other specimens attributed to the species by Stensiö (1932).

Description-Of the two Wayne Herbert specimens, one has a larger headshield (NHM P16310, 99mm long, 96mm maximum width, 74mm midline headshield length) and other smaller (P19198-9, 76mm long, 87mm wide, 58mm midline headshield length). The pineal plate is short, well defined and enlarged medially. The prepineal division of both shields constitutes approximately $48 \%$ of the midline headshield length. The orbital openings are roughly circular and enclosed within thin circumorbital raised rims (Fig. 4). The nasohypophsial opening is anteroposteriorly elongate and exhibits a slightly expanded hypophysial division relative to the nasal division. In specimen P16310 the nasohypophysial opening is found within a shallow circumnasal depression. The median field is approximately octagonal, tapering anteriorly at the level of the posterior margin of the circumorbital raised rims. The lateral fields measure $50-61 \mathrm{~mm}$, extend over $25-28 \%$ of the cornual processes and terminate posteriorly with pointed margins. The cornual processes measure $28-41 \mathrm{~mm}$, constituting approximately $37-41 \%$ of maximum shield length. They are medially curved, with the effect that the maximum headshield width occurs at a level approximately midlength of the cornual processes. The abdominal division is short, constituting approximately $19-22 \%$ of the midline shield length, and bears a low dorsal median ridge. The abdominal division of p19198-9 is fairly broad where as that of P16310 appears to taper posteriorly, 
producing extremely broad pectoral sinuses. The nature of the shields preservation makes it difficult to discern whether the specimen is in fact missing the lateral margins of its abdominal division. P16310 preserves ornament of the headshield tesserae comprising 7-10 large rounded and evenly spaced tubercles surrounding a slightly enlarged central tubercle. The ornamentation of the ventral rim is unknown in the Wayne Herbert specimens.

Remarks-The species is distinguished from other Wayne Herbert species by the shape of its lateral and median fields, the presence of a low median ridge, and by its ornament. One specimen attributed to this species (p16310) was described by White (1932) as Cephalaspsis jacki. White distinguishes the species from Zenaspis salweyi Egerton, 1857 by its longer and more slender cornual processes, its wider and shallower pectoral sinuses and it less developed dorsal median ridge. C. jacki most closely resembles Cephalaspis whitei Stensiö 1932, published marginally before. The Wayne Herbert specimens fall within the size range of ' $C$ '. whitei identified by Stensiö (1932) (midline headshield length 45-70mm), although P16310 slightly exceeds the size of the largest ascribed specimen. Both specimens from Wayne Herbert differ from the holotype, however, which exhibits a median field which extends onto the abdominal division, as well as elongate tubercles on the interior margins of the cornual processes. Stensiö (1932) regarded the later character as diagnostic for the species. Examination of the attributed material, however, reveals that the posterior extent of the median field is variable rather than a discrete character which could be used to distinguish between species. Furthermore the absence of tubercles on the interior margins of the cornual processes could easily reflect differences in preservation or preparation (see above). The Wayne Herbert specimens are attributed to Pattenaspis whitei (which takes priority over $C$. jacki White 1932) on the basis of their shield breadth, fairly long prepineal division, long, medially curved cornual processes, and characteristic median and lateral field shape as well as ornamentation of the headshield tesserae (preserved in P16310) which is indistinguishable from that of the holotype. P. whitei compares closely with ' $C$ '. fletti Stensiö, 1932; both species share a similar headshield outline as well as broad lateral fields with pointed posterior margins that extend considerably onto long, medially curved cornual processes bearing spiny tubercles on their interior margins. ' $C$ '. fletti is distinguished from $P$. whitei however by its shorter prepineal division, its narrower lens shaped median field and its ornamentation consisting of large obtuse tubercles restricted to the lateral and rostral margins of the shield (Stensiö, 1932). P.whitei also compares closely with ' $C$ '. whitbachensis Stensiö, 1932 which differs from ' $C$ '. fletti only in the lack of tubercular ornamentation. It is speculated here that ' $C$ '. whitbachensis and ' $C$ '. fletti are synonymous and that the lack of ornamentation may be 
the result of taphonomic differences rather than taxonomic disparity. The disparity between ' $C$ '. fletti and ' $C$ '. whitei is considered taxonomically significant at the species level in the current study, yet could potentially be eroded if subject to a more complete revision of all material attributed to these species. Furthermore, additional study of ' $C$.' fletti and ' $C$.' whitbachensis will be necessary to assess whether they are appropriate for inclusion in Pattenaspis.

CORNUATA gen. indet. sp. A

(Figs 6A,C, 7)

Material-P19229 (Fig. 6A,C)

Description - The headshield of this specimen attains a maximum length of $58 \mathrm{~mm}$ with a maximum width exceeding $60 \mathrm{~mm}$. The midline headshield length likely exceeded $53 \mathrm{~mm}$. The prepineal division measures $26 \mathrm{~mm}$ therefore constituting $>49 \%$ of midline headshield length. The shield is narrow towards the rostral margin. The lateral fields are short and broad throughout their entire length, attaining a length of approximately $41 \mathrm{~mm}$ and terminating slightly before the level of the pectoral sinuses. The median field is fairly long and broad with approximately parallel straight lateral margins; its width constituting roughly $48 \%$ of its length. The pineal plate is short and very narrow. The hypophysial division of the nasohypophysial opening is expanded relative to the nasal division. It lies within a narrow and shallowly depressed circumnasal depression. The orbital openings are fairly large in proportion to the shield size, oval shaped and lack circumorbital raised rims. The pectoral sinuses are narrow, bordering a broad and short abdominal division exceeding $23 \%$ of the shields length in midline. The posteriorly projected cornual processes are extremely short and gracile, their length constituting $22 \%$ of the maximum headshield length. Only the basal laminar layer of tissue is preserved therefore shield ornament cannot be observed.

Remarks-The headshield of this morphogroup is remarkable in its shape and proportions which are without close comparison. Exceptionally short cornual processes are known in a number of taxa; notably Diademaspis poplinae Janvier, 1985a, 'Cephalaspis' lornensis Traquair, 1898 and C. cradleyensis Stensiö, 1932. The specimen described here has lateral fields which are limited in the degree to which they extend over the cornual processes, a characteristic it shares with D. poplinae. D. poplinae is, however, much larger with fundamentally different shield morphology. ' $C$ '. lornensis offers perhaps the closest comparison to the specimen. Both share fairly large orbital openings in proportion to shield size, a roughly similar shaped median field, a broad abdominal division, narrow pectoral 
sinuses and lateral fields that do not extend onto the cornual processes. ' $C$ '. lornensis differs from the specimen, however, in its short and broad prepinieal division and its more robust cornual processes. With C. cradleyensis, this specimen shares fairly large orbital openings in proportion to shield size, a prepineal division constituting around $50 \%$ of the midline shield length and a broad abdominal division with adjacent narrow pectoral sinuses. However the shield of $C$. cradleyensis remains broad anteriorly and exhibits a narrow lens shaped median field and the lateral fields that extend well onto the cornual processes. The specimen thus likely represents a new species characterised by its short and thin cornual processes, narrow rostrum and limited posterior extent of its lateral fields. Unfortunately the current material is incomplete to the extent that the morphology of the abdominal division, as well as the nature of shields ornamentation, is completely unknown. Accordingly the specimen is retained in open nomenclature.

\section{CORNUATA gen. indet. sp. B}

(Figs 6B,D, 7)

\section{Material-P24922/3 (Fig. 6B,D)}

Description - The headshield of this single specimen attains a maximum length of approximately $43 \mathrm{~mm}$ with a maximum width, measured slightly above the tips of the cornual processes, approximately $54 \mathrm{~mm}$. The shield measures an estimated $39 \mathrm{~mm}$ in midline headshield length. The shield is fairly broad, particularly towards the anterior where the shield rapidly narrows to produce a blunt rostral margin. The prepineal division constitutes approximately $49 \%$ of the shield length in midline. No trace of the lateral fields can be seen, however it is unclear whether the shield originally lacked lateral fields or, perhaps more likely, they have not been preserved. The median field is poorly preserved and its posterior extent is unknown. The nasohypophysial opening cannot be observed although a shallow, short and narrow circumnasal depression exists directly above the thin and poorly preserved pineal plate. The orbital openings are roughly circular and lack circumorbital raised rims. The pectoral sinuses are broad and deep. The abdominal division constitutes approximately $30 \%$ of the midline shield length and does not appear to bear a dorsal median ridge. The cornual processes are extremely robust and project posterolaterally, slightly curving medially at their tips. They constitute roughly $32 \%$ of the shields maximum length. Posterior to the headshield, the articulated body is preserved, with up to 15 scale rows observed. It is twisted laterally and compressed into a single plane with the effect that venterolateral scales are observed on the left margin, while dorsal median ridge scales occur close to the right margin. Tesserae of the 
shield are well preserved. Their size is variable with small units occurring posteromedially and extremely large units occurring towards the rostral and lateral margins of the shield. They are ornamented with minute and closely set tubercles which exhibit a random distribution producing a granular texture within the centre of each unit, yet are differentiated into discrete rows towards the margins of the tesserae. The largest tesserae exhibit up to 30 rows of tubercles. The ventral rim appears to be similarly ornamented. The scales of the body are ornamented with minute rows of closely set tubercles.

Remarks-The single specimen of this morphogroup bears some resemblance to that of Cephalaspis lankesteri Stensiö, 1932; both share long and robust cornual processes and broad pectoral sinuses. In addition, Stensiö's (1932) shield reconstruction shares a similar outline to that of the specimen i.e. prenounced anterior-lateral corners of the headshield margin. However, C. lankesteri may be distinguished by its narrower rostral margin, the presence of a dorsal median ridge and the lack of tubercular ornamentation producing a smooth dorsal shield surface. Specimen P24922-3 can be distinguished from other cornuate Osteostraci by its broad prepineal division with a blunt rostral margin and by the presence of large tesserae ornamented with rings of minute closely set tubercles. The extent of the median field cannot be determined accurately at present and the morphology of the lateral fields is completely unknown. Consequently the specimen is retained in open nomenclature.

\section{THE STATE OF OSTEOSTRACAN TAXONOMY}

Application of this morphogroup approach to the taxonomy of the Wayne Herbert fauna and subsequent comparison with previously described species of Osteostraci highlights important difficulties with the current state of osteostracan taxonomy at both species and genus level. Difficulties with genus level taxonomy need consideration from a historic perspective. The first osteostracan taxon to be erected was Cephalaspis lyelli Agassiz 1835 which designates a single part and counterpart (NHM 20087/P3233). Unfortunately over 100 years passed before a detailed description of this specimen was published (White, 1958) and in the intervening time period many generalised cornuate Osteostraci were assigned to the genus Cephalaspis despite possessing characters which distinguish them from this genus (Janvier and Newman, 2004). Janvier and Newman (2004) suggest that C. lyelli can be distinguished from most other generalised forms by its long prepineal division, narrow median field and approximately parabolic anterior shield margin. Only 3 species (C. producta Wängsjö, 1952, C. Cradleyensis Stensiö, 1932 and C. sollasi Stensiö, 1932) demonstrate 
comparable morphology, thus are regarded as more closely related to $C$. lyelli than to any other osteostracan (Janvier 1985a, 1985b, Janvier unpublished data). The genus name Cephalaspis may therefore be retained for these species. A number of generalised forms assigned to Cephalaspis have since been recognised as distinct genera (e.g. Denison, 1951; Jarvik, 1954; Stensiö, 1958; Janvier 1976, 1985a, 1985b) however many species remain assigned to Cephalaspis that exhibit none of the derived characters which distinguish this genus. Clarity is therefore needed regarding these many species of 'Cephalaspis' to provide a better taxonomic framework and context for investigations of diversity and phylogeny (Sansom 2009a). Unfortunately a genus level taxonomic revision of cornuate Osteostraci is beyond the scope of this study. Of the morphogroups identified in the Wayne Herbert fauna, two have been assigned to Janaspis gen. nov., one to Pattenaspis and two have been described as Cornuata gen. indet. This reflects current taxonomic limitations and it is anticipated that these species will be attributed to different or new genera once the taxonomy of Cephalaspis is revised.

Regarding species level taxonomy of Osteostraci, it is apparent that there may have been a historic tendancy for 'over-splitting' of species. Three main causes are suggested. Firstly, species have been erected on the basis of fragmentary material which is character deficient and thus cannot be meaningfully compared with previously erected taxa. Cephalaspis sollasi Stensiö 1932, for example, was erected on the basis of one incomplete specimen which is identifiable as Cephalaspis but lacks any diagnostic features that could be used to reliably distinguish it from $C$. lyelli (for which the cephalic shield ornamentation is also unknown). Secondly, taphonomy of specimens has been inadequately considered. The presence and number of tubercles on the interior margins of the cornual processes has been used as key diagnostic feature (Stensiö 1932), but for species for which only a few specimens are known, it is not possible to discern if tubercles are absent due to poor preservation rather than original condition. Thirdly, an over reliance on continuous rather than discrete characters within species diagnoses can lead to ambiguity. Whilst continuous characters, such as cornual process size, orbit size or median field size, may be taxonomically informative and have been used to differentiate some species (e.g. Zenaspis dzieduszyckii Voichyshyn, 2006), these may easily represent end members of a spectrum of morphological variation exacerbated by missing intermediates (Sansom 2007). We therefore suggest that continuous characters are supported by discrete characters.

A potential solution to the problems of taxonomic ambiguity is provided by the ornamentation of the dermoskeleton of the cephalic shield. We have documented 
considerable variability in ornament, and differences in ornamentation of the headshield tesserae, ventral rim, and circumorbital raised rims might prove to be taxonomically useful characters.

\section{GROWTH OF OSTEOSTRACI}

Osteostraci possess complex dermoskeletal tissues comprising a composite of cellular and acellular bone like to that of jawed vertebrates, particularly placoderms (Donoghue and Sansom 2002; Donoghue et al., 2006). It has been assumed that ossification of the osteostracan dermoskeleton began only once an individual attained adult size, and that development of the dermal armour effectively inhibited further growth (Stensio, 1927, 1932; Denison 1952; Janvier, 1996). This differs from the condition recognized in primitive gnathostomes which typically demonstrate indeterminate growth (Hawthorn et al., 2008; Cloutier, 2010). Given the phylogenetic position of the Osteostraci as the sister group to all jawed vertebrates (Forey and Janvier, 1993; Janvier 1996; Donoghue et al., 2000) it follows that recognising patterns of dermoskeletal growth within the Osteostraci is informative regarding the pleisiomorphic state of jawed vertebrate dermoskeletal development.

Until recently, evidence of osteostracan growth has been limited to recognition of incompletely mineralised dermoskeletal units (Dineley and Loeffler, 1976; Janvier, 1985a; Belles-Isles, 1989), deposition and resorption of dentine and bone (Denison, 1952) and intraspecific headshield size variation (White and Toombs, 1983; Janvier, 1985a; Janvier and Arsenault ,1996; Sansom, 2007; see also Hawthorn et al., 2008). Such observations are of limited use when considering patterns of ossification through ontogeny. A recent study by Hawthorn et al. (2008) was able to address this issue, however, through identification of the ontogenetic sequence of the Lochkovian cornuate osteostracan Superciliaspis gabrielsei Dineley and Loeffler, 1976. Hawthorn et al., were able to provide a comprehensive model for growth of the tessellate osteostracan dermoskeleton, adapted from Halstead Tarlo's (1967) model of dermoskeleton growth in tessellate heterostracans. They suggest that each tessera grew individually by means of marginal addition of skeletal tissue. Ossification is suggested to have initiated by development of a 'primordial' central tubercle with an internally open pulp cavity. This was followed by marginal ossification of tuberculated rings of bone and finally through addition of untuberculated rings (Fig. 8). Furthermore they observe tesserae at different developmental stages present within individual shields suggesting the headshield grew through a combination of addition of new tesserae as well as centrifugal addition of tissue to existing tesserae. Postcranially, the squamation pattern of adult specimens, 
comprising large rectangular scales, is suggested to have formed as a result of fusion of smaller scales. The model presented by Hawthorn et al. (2008) differs from that of Halstead Tarlo (1967) which suggests the tessellate dermoskeleton of some heterostracans is a product of individual centrifugally growing units abutting together as the headshield becomes fully encased in bone, thereby inhibiting further growth. In contrast Hawthorn et al. (2008) recognise 'adolescent' specimens which demonstrate a fully ossified dermal skeleton composed of incompletely developed tesserae implying is that Superciliaspis gabrielsei was capable of indeterminate growth. Superciliaspis gabrielsei, however, is a fairly derived osteostracan with unusual dermoskeletal histology (Dinely and Loeffler, 1976; Hawthorn et al., 2008; Sansom 2009a). It thus remains unclear whether this model of dermoskeletal growth reflects the pleisiomorphic condition of tessellate growth within the Osteostraci.

Two species of Osteostraci from Wayne Herbert (Diademaspis janvieri and Cornuata gen. indet. sp. B) demonstrate dermoskeletal growth patterns which support the model of centrifugal growth proposed by Hawthorn et al. (2008). The growth pattern of Cornuata gen. indet. sp. B is most comparable to that of Superciliaspis gabrielsei. The shield of the single specimen attributed to the species exhibits tesserae of varying size; the largest of which are ornamented with up to 30 concentric rings of tubercles surrounding undifferentiated central tubercles, while the smallest tesserae are entirely undifferentiated, lacking tubercle rings. It suggests that ossification began with the development of 'primordial' small tesserae with undifferentiated tubercles which subsequently grew by means of marginal addition of tuberculated rings of bone (see fig. 8). Presently it cannot be determined whether these undifferentiated units developed by means of centrifugal or synchronous ossification, yet the strong polygonal pattern of the tubercle rings indicates that tesserae were already abutting during marginal ossification (Halstead Tarlo 1967, Halstead 1973), thus supporting the hypothesis that osteostracans were capable of indeterminate growth. The smallest and least well ossified of the Superciliaspis gabrielsei specimens, interpreted as most juvenile, already exhibit a well ossified cephalic brim (Hawthorn et al., 2008), indicating ossification may have initiated marginally. A similar conclusion may be drawn from the size distribution of tesserae observed in Cornuata gen. indet. sp. B, wherein the largest units, exhibiting the most tubercle rings, occur at the margins of the shield with smaller units comprising fewer tubercle rings occurring towards the shield's centre.

The complex and variable dermoskeletal ornamentation of Diademaspis janvieri is more difficult to interpret in terms of growth patterning. Ostensibly, each tessera comprises central large tubercles surrounded by up to 3 rows of minute tubercles; a pattern indicative of 
centrifugal growth by means of marginal addition of tuberculated 'rings'. However, close inspection of the high fidelity dermoskeletal impressions of specimens P20005a and P24942 reveals surprising variation in the number of central tubercles, as well as the number of 'rings' of minute tubercles, occurring within tesserae. The simplest tessera comprises a single central tubercle surrounded by 2 'rings' of minute tubercles however, up to 7 large tubercles may form a central 'island' enclosed within several 'rings' of tuberculated bone. Following the models presented by Halstead Tarlo (1967) and Hawthorn et al., (2008) the large central tubercle may be regarded as primordial discrete ossification centres which formed within the skin of the 'naked' animal, however in contrast to previous models these seem to have frequently fused together producing 'islands' of large tubercles before subsequent centrifugal addition of tuberculated 'rings' of bone. Several tesserae forming part of the shield of specimen P20005a are observed to share the exterior most 1-2 tuberculated 'rings' while possessing separate interior most 'rings'. This pattern may have arisen as a result of fusion between two independent tessaerae into a single larger plate. One means of attaining such fusion would be a reduction or ceasing of ossification at the abutting margins, allowing the formation of continuous rings of tuberculated bone to envelope adjacent tesserae (Fig. 8). The tuberculated 'rings' demonstrate a polygonal pattern, much as in Superciliaspis gabrielsei (Adrain and Wilson, 1994; Hawthorn et al., 2008) indicating that the headshield tesserae of Diademaspis janvieri were capable of indeterminate growth following abutting of the tesserae. D. janvieri demonstrates a more complex growth pattern than has been previously described and provides evidence for superficial fusion of independent centrifugally growing tesserae within the Osteostraci.

\section{CONCLUSIONS}

The generalised cornuate osteostracan morphology presents a challenge to taxonomists. There are few discrete characters which can be used to differentiate species and this has lead to a historic tendency to instead establish species based on character deficient, poorly preserved and/or fragmentary material with inadequate consideration of taphonomic character loss and an over reliance on continuous rather than discrete characters. The osteostracan fauna of Wayne Herbert quarry, however, has been subject to a step-wise quantitative and qualitative analysis of morphology, permitting recognition of 7 morphogroups. After comparison with existing descriptions, it has been possible to recognise two new species of Zenaspididae (Zenaspis wayenensis and Diademaspis janvieri) as well as 
two new species of Cornuata incertae sedis (Janaspis newtonensis and Janaspis punctata).

This approach has ensured that species identification accurately reflects intra- and inter-taxon variation within the fauna. The high fidelity preservation of osteostracan material from Wayne Herbert also reveals ornamentation patterns which provide support for models of indeterminate growth within the Osteostraci. These new taxonomic results and anatomical data enable a better understanding of the diversity and development of the Osteostraci and will help to elucidate the evolutionary diversification of this intriguing group.

\section{ACKNOWLEDGEMENTS}

Firstly, the authors are indebted to E. White who originally collected and prepared the material and was intending to describe it before his passing. P. Forey (formally NHM) is thanked for initially making the authors (R. Sansom) aware of the material and its context. Z. Johanson (NHM) is thanked for enabling access and loan of the material and D. Unwin (Leicester) for providing transport.

\section{LITERATURE CITED}

Adrain, J. M. and M. V. H. Wilson. 1994. Early Devonian cephalaspids (Vertebrata: Osteostraci: Cornuata) from the southern Mackenzie Mountains, N.W.T., Canada. Journal of Vertebrate Paleontology 14:301-319.

Affanassieva, O. B. 1989. [New cephalaspids (agnatha) from the Lower Devonian of Podolia]. Palaeontologičeskij žurnal 3:51-59. [Russian]

Agassiz, J. L. R. 1835. Reserches sur les Poissons Fossiles. 2. Contenant l'histoire de l'ordre des Ganoïdes. Neuchâtel 85-300pp.

Allen, J. R. L. and L. B.H. Tarlo. 1963. The Downtonian and Dittonian facies of the Welsh Borderland. Geological Magazine 100,129-155.

Balabai, P. P. 1962. [The fauna of the cephalaspids of Podolian plate]. Naukovi zapysky Naukovo-pryodo-znavčogomuzeâ AN URSR 10:3-8. [Ukranian]

Belles-Isles, M. 1989. Yvonaspis, nouveau genre d'Osteostraci (Vertebrata, Agnatha) du Dévonien (Emsien-Eifélien) des Grès de Gaspé (Québec, Canada). Canadian Journal of Earth Sciences 26:2396-2401.

Bengtson, P. 1988. Open nomenclature. Palaeontology 31:223-227. 
Blieck, A. R. M. 1984. Les Hétérostracés ptéraspidiformes, Agnathes du Silurien-Dévonien du continent Nord-Atlantique et des blocs avoisinants. Cahiers de Paléontologie, Centre National de la Recherche Scientifique, Paris, 199 pp.

Blieck, A. R. M., and Janvier, P. 1989. Vertébrés agnathes du Dévonieen Inférieur de l'Artois(Pas-de-Calais, France): Implication biostratigraphiques. Annales de Paléontologie 75:125-167.

Brazeau, M. D. 2009. The braincase and jaws of a Devonian 'acanthodian' and modern gnathostome origins. Nature 457:305-308.

Cloutier, R. 2010. The fossil record of fish ontogenies: Insights into developmental patterns and processes. Seminars in Cell \& Developmental Biology 21:400-413.

Coates, M. I. 2003. The evolution of paired fins. Biomedical and Life Sciences 122:266-287.

Denison, R. H. 1951. Evolution and classification of the Osteostraci. Fieldiana: Geology 11:156-196.

Denison, R. H. 1952. Early Devonian Fishes from Utah. Part 1. Osteostraci. Fieldiana: Geology 11:265-287.

Dineley, D. L. 1999. Late Silurian fossil fish sites of the Welsh Borders; pp. 63-106 in D. L. Dineley and S. J. Metcalf (eds), Fossil Fishes of Great Britain. Joint Nature Conservation Committee, Peterborough, UK.

Dineley, D. L., and J. Loeffler. 1976. Ostracoderm faunas of the Delorme and associated Siluro-Devonian Formations, North West Territories, Canada. Palaeontological Association Special Papers in Palaeontology 18:1-214.

Donoghue, P. C. J., P. L. Forey, and R. J. Aldridge 2000. Conodont affinity and chordate phylogeny. Biological Reviews 75:191

Donoghue, P. C. J. and I. J. Sansom. 2002. Origin and early evolution of vertebrate skeletonization. Microscopy Research Techniques 59:352-372.

Donoghue, P C. J., I. J. Sansom and J. P. Downs. 2006. Early evolution of vertebrate skeletal tissues and cellular interactions, and the canalization of skeletal development. Journal of Experimental Zoology Part B: Molecular and Developmental Evolution 306:117.

Egerton, P. M. G. 1857. Palichthyologic notes. No. 9. On some fish-remains from the neighbourhood of Ludlow. Quarterly Journal of the Geological Society of London 13:282-289.

Forey, P. L., and P. Janvier. 1993. Agnathans and the origins of jawed vertebrates. Nature 361:129-134. 
Friman, L., and P. Janvier. 1986. The Osteostraci (Vertebrate, Agnatha) from the Lower Devonian of the Rhenish Slate Mountains, with special reference to their anatomy and phylogenetic position

Halstead, L. B. 1973. The heterostracan fishes. Biological Reviews of the Cambridge Philosophical Society 48:279-332.

Halstead Tarlo, L. B. 1967. Agnatha, 629-636 pp. in Harland, W. B., C. H. Holland, M. R. House, N. F. Hughes, A. B. Reynolds, M. J. S. Rudwick, G. E. Satterthwaite, L. B. H. Tarlo, E. C. Willey (eds). The Fossil Record. London Geological Society, London.

Hawthorn, J. R., M. V. H. Wilson and A. B. Falkenberg. 2008. Development of the dermoskeleton in Superciliaspis gabrielsei (Agnatha: Osteostraci). Journal of Vertebrate Paleontology, 28:951-960.

Janvier, P. 1976. Hildenaspis digitalis nov. gen., nov. sp.(Agnatha, Cephalaspidomorphi), Cephalaspide nouveau du Devonien inferieur d'Allemagne. Geobios 9:223-225.

Janvier, P. 1981. The phylogeny of the Craniata, with particular reference to the significance of fossil "agnathans". Journal of Vertebrate Paleontology 1:121-159.

Janvier, P. 1985a. Les Céphalaspides du Spitsberg. Cahiers de Paléontologie, Section Verébrés, Éditions du Centre National de la Récheŕe Scientifique, Paris, 183-195pp.

Janvier, P. 1985b. Preliminary description of Lower Devonian Osteostraci from Podolia (Ukrainian S.S.R.). Bulletin of the British Museum (Natural History), Geology 38:309334.

Janvier, P. 1996. Early Vertebrates. Oxford University Press, Oxford, 408pp.

Janvier, P., and M. Arsenault. 1996. Osteostraci; 123-133pp in Schultze, H. P. and R. Cloutier (eds.), Devonian Fishes and Plants of Miguasha, Quebec, Canada, Friedrich Pfeil, Munich.

Janvier, P. and M. J. Newman. 2004. On Cephalaspis magnifica Traquair, 1893, from the Middle Devonian of Scotland, and the relationships of the last osteostracans. Transactions of the Royal Society of Edinburgh: Earth sciences. 95:511-525

Janvier, P., M. Arsenault and S. Desbiens. 2004. Calcified cartilage in the paired fins of the osteostracan Escuminaspis laticeps (Traquair 1880), from the Late Devonian of Miguasha (Québec, Canada), with a consideration of the early evolution of the pectoral fin endoskeleton in vertebrates. Journal of Vertebrate Paleontology 24:773-779.

Jarvik, E. 1954. On the visceral skeleton in Eusthenopteron with discussion of the paraspenoid and palatoquadrate in fishes. - Kungliga Svenska Vetenskapsakademiens Handlingar, Fjäirde Serien 5:1-104. 
Lankester, E. R. 1870. A monograph of fishes of the Old Red Sandstone of Britain. Part I. The Cephalaspidae. The Palaeontographical Society, London, 62pp.

Matthews, S. C. 1973. Notes on open nomenclature and on synonymy lists. Palaeontology, 16:335-380.

Miles, R. S. 1973. Articulated acanthodian fishes from the Old Red Sandstone of England, with a review of the structure and evolution of the acanthodian shoulder-girdle. Bulletin of the British Museum (Natural History), Geology, 24:113-213.

Patten, W. 1903. On the structure of the Pteraspidae and Cephalaspidae. The American Naturalist 37:827-865.

Sansom, R. 2007. A review of the problematic osteostracan genus Auchenaspis and its role in Thyestidian evolution. Palaeontology 50:1001-1011.

Sansom, R. S. 2008. The origin and early evolution of the Osteostraci (Vertebrata): a phylogeny for the thyestiids. Journal of Systematic Palaeontology 6:317-332.

Sansom, R. S. 2009a. Phylogeny, classification and character polarity of the Osteostraci (Vertebrata). Journal of Systematic Palaeontology 7:95-115.

Sansom, R. S. 2009b. Endemicity and palaeobiogeography of the Osteostraci and Galeaspida: A Test of scenarios of gnathostome evolution. Palaeontology 52:12571273.

Sansom, R. S., S. A. Rodygin, and P. C. J. Donoghue. 2008. The anatomy, affinity and phylogenetic significance of Ilemoraspis kirkinskayae (Osteostraci) from theDevonian of Siberia. Journal of Vertebrate Paleontology 28:613-625.

Stensiö, E. A. 1927. The Downtonian and Devonian vertebrates of Spitsbergen. 1. Family Cephalaspidae. Skrifter om Svalbard og Ishavet 12:1-391.

Stensiö, E. A. 1932. The Cephalaspids of Great Britain. British Museum (Natural History), London, 220pp.

Stensiö, E. A. 1958. Les cyclostomes fossiles ou ostracodermes; pp 173-425 in Grassé, P. P. (ed.), Traité de Zoologie, Paris.

Schmitz, B., G. Åberg, L. Werdelin, P. Forey and S. E. Bendix-Almgreen. ${ }^{87} \mathrm{Sr} /{ }^{86} \mathrm{Sr}, \mathrm{Na}, \mathrm{F}$, $\mathrm{Sr}$, and $\mathrm{La}$ in skeletal fish debris as a measure of the paleosalinity of fossil-fish habitats. Geological Society of America Bulletin 103:789-794.

Traquair, R. H. 1898. Report on fossil fishes. Summary of progress of the Geological Survey of the United Kingdom, Memoirs, 1897:72-76.

Voichyshyn, V. 2006. New osteostracans from the Lower Devonian terrigenous deposits of Podolia, Ukraine. Palaeontologica Polonica 51:131-142. 
Voichyshyn, V. 2011. The Early Devonian armoured agnathans of Podolia, Ukraine. Palaeontologia Polonica 66:1-211.

Wängsjö, G. 1952. The Downtonian and Devonian Vertebrates of Spitsbergen. IX. Morphologic and systematic studies of the Spitsbergen Cephalaspids. Results of Th.Vogt's Expedition 1928 and the English-Norwegian-Swedish Expedition 1939. Norsk Polarinstitutt Skrifter 97:1-611.

White, E. I. 1932. Note on new discoveries of Lower Old Red Sandstone vertebrates in Herefordshire. Transactions of the Woolhope Naturalists' Field Club 179-191pp.

White, E. I. 1935. The Ostracoderm Pteraspis Kner and the relationships of the agnathous vertebrates. Philosophical Transactions of the Royal Society of London. Series B, Biological Sciences 225:381-457.

White, E. I. 1958. On Cephalaspis lyelli Agassiz. Palaeontology 1:99-105.

White, E. I. and H. A. Toombs. 1983. The Cephalaspids from the Dittonian section at Cwm Mill, near Abergavenny, Gwent. Bulletin of the British Museum, Natural History. Geology 37:149-171.

Woodward, H. 1881. Note on the fine headshield of Zenaspis (Cephalaspis) salweyi, Egerton sp. = Cephalaspis asterolepis (Harley). Geological Magazine 8:193-194.

FIGURE 1. Dimensions of an osteostracan headshield that were collected in order to quantitatively characterize specimens. [planned for column width]

FIGURE 2. Zenaspis waynensis sp. nov. A. NHM P24940; B. P23832; C. Interpretation of P24940. To scale (20mm) except C. Abbreviations - cp, cornual process; cr circumorbital raised rim; hd hypophysial division of nasohypophysial opening; lf, lateral field; mf, median field; mr, median ridge; nd, nasal division of nasohypophysial opening; o, orbit; pf, paired pectoral fin; pp, pineal plate; $\mathbf{t}$, tessera. [planned for page width]

FIGURE 3. Diademaspis janvieri sp. nov. A. NHM P20005; B. P16602; C. P24941; D. Interpretation of P24941.To scale (20mm) except D. Abbreviations-as for figure 2. [planned for two thirds page width]

FIGURE 4. Janaspis newtonensis sp. nov. and Pattenaspis whitei. A. J. newtonensis NHM P17488; B. Interpretation of P17488; C. P. whitei, interpretation of P19198; D. P. whitei 
P19198; E. P. whitei P16310. To scale (20mm) except B, C. Abbreviations-as for figure 2. [planned for page width]

FIGURE 5. Janaspis punctata sp. nov. A. NHM P20004; B. P24924; C. P16606; D. P24935; E. P24920; F Interpretation of . To scale (20mm) except F. Abbreviations-as for figure 2. [planned for page width]

FIGRE 6. Cornuata gen. indet. sp. A and sp. B. A. sp. A NHM P19299; B. sp. B. P24922; C. Interpretation of P19299; D. Interpretation of PP24922. To scale (20mm) except C, D. Abbreviations - as for figure 2. [planned for two thirds page width]

FIGURE 7. Reconstructions of the headshields of the Wayne Herbert osteostracan fauna. To scale $(20 \mathrm{~mm})$. [planned for page width]

FIGURE 8. Growth stages of headshield tesserae of three osteostracan species: A. Superciliaspis gabrielsei reproduced from Hawthorn et al. (2008), with ossification of primordial tubercle followed by rings of tubercles and bones around; B. Cornuata gen. indet. sp. B, from simplest discernable unit of a tesserae plate with undifferentiated tubercles, followed by centrifugal addition of up to 30 tuberculated 'rings' of bone; C. Diademaspis janvieri sp. nov. from simplest discernable unit of individual large tubercles followed by fusion of up to 7 central tubercles surrounded by rings and then either individual tesserae fusing together by addition of tuberculated rings of bone enclosing the two separate units or growing as individual abutting units via marginal addition of tuberculated 'rings'. [planned for two thirds page width]

FIGURE 9. Reconstruction of Diademaspis janvieri sp. nov. [planned for column width] 
32

33

34

35

36

37

38

39

40

41

42

43

44

45

46

47

48

49

50

51

52

53

54

55

56

57

58

59

60

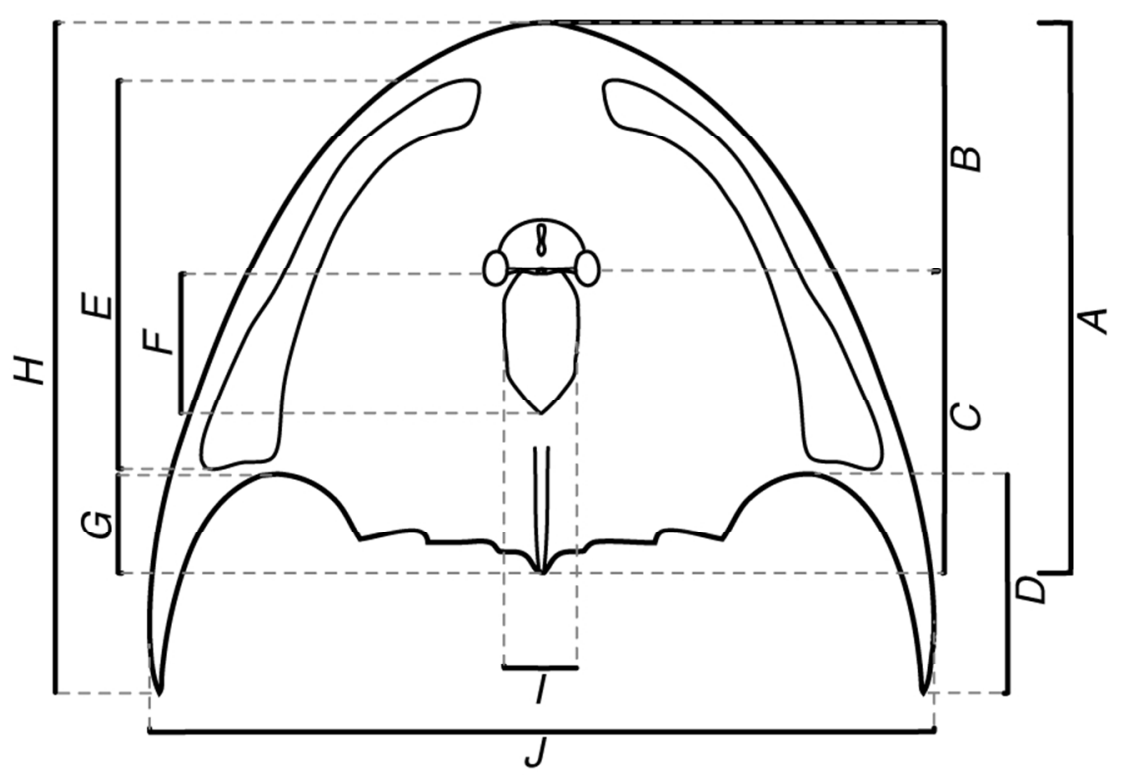

Dimensions of an osteostracan headshield that were collected in order to quantitatively characterize specimens. $90 \times 54 \mathrm{~mm}(300 \times 300$ DPI $)$ 

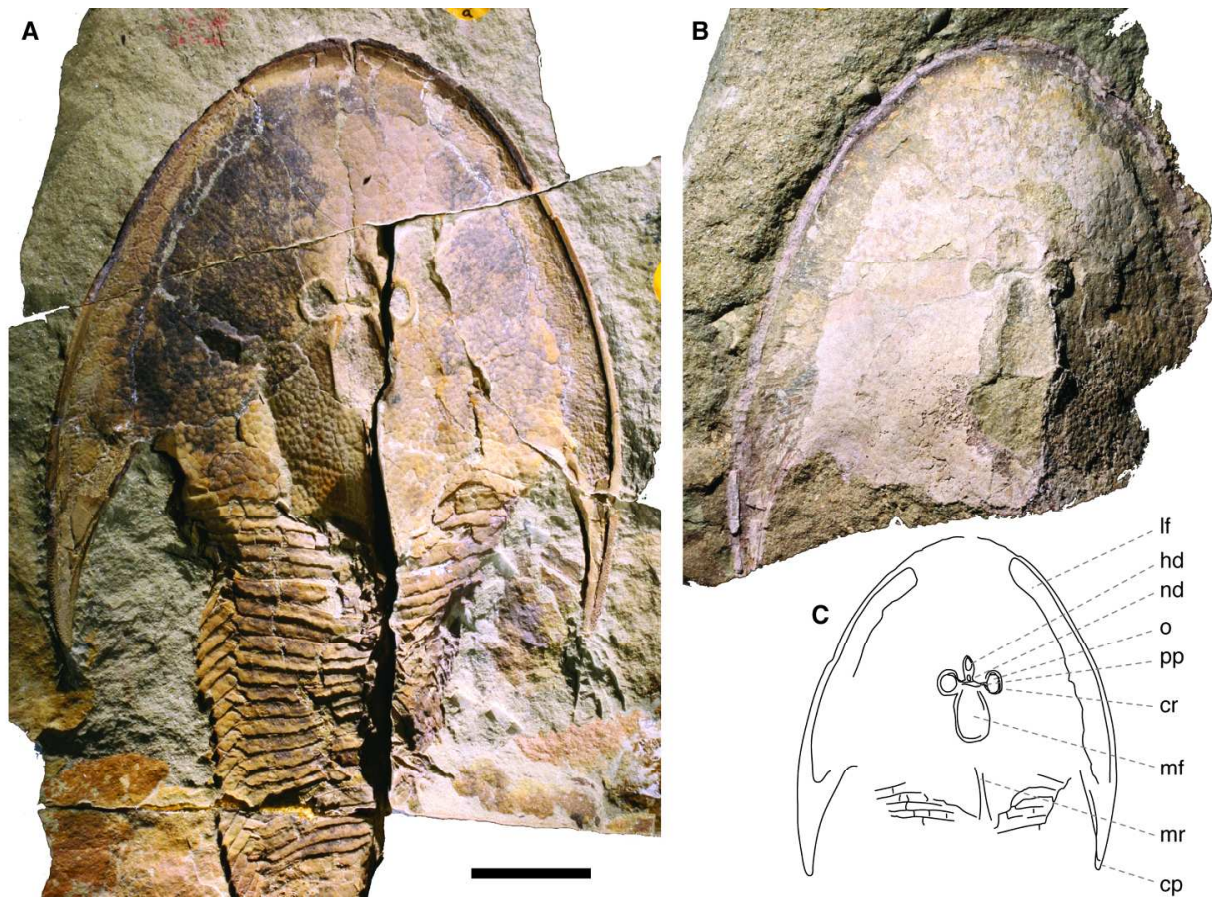

Zenaspis waynensis sp. nov. A. NHM P24940; B. P23832; C. Interpretation of P24940. To scale (20mm) except C. Abbreviations-cp, cornual process; cr circumorbital raised rim; hd hypophysial division of nasohypophysial opening; If, lateral field; $\mathrm{mf}$, median field; $\mathrm{mr}$, median ridge; nd, nasal division of nasohypophysial opening; o, orbit; pf, paired pectoral fin; $p p$, pineal plate; $t$, tessera. $182 \times 124 \mathrm{~mm}(300 \times 300 \mathrm{DPI})$ 

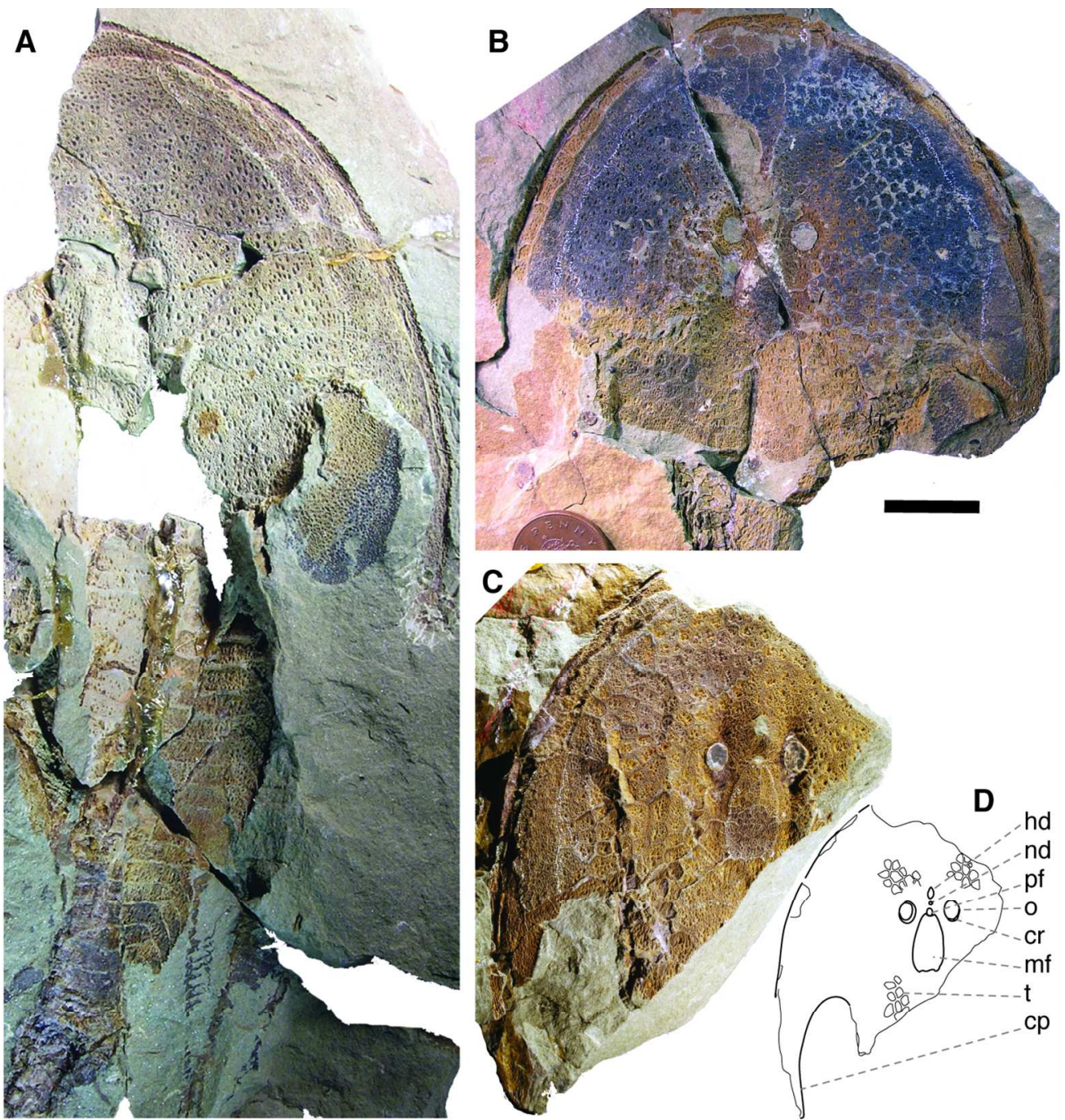

Diademaspis janvieri sp. nov. A. NHM P20005; B. P16602; C. P24941; D. Interpretation of P24941.To scale $(20 \mathrm{~mm})$ except $\mathrm{D}$. Abbreviations-as for figure 2. $120 \times 127 \mathrm{~mm}(300 \times 300 \mathrm{DPI})$ 

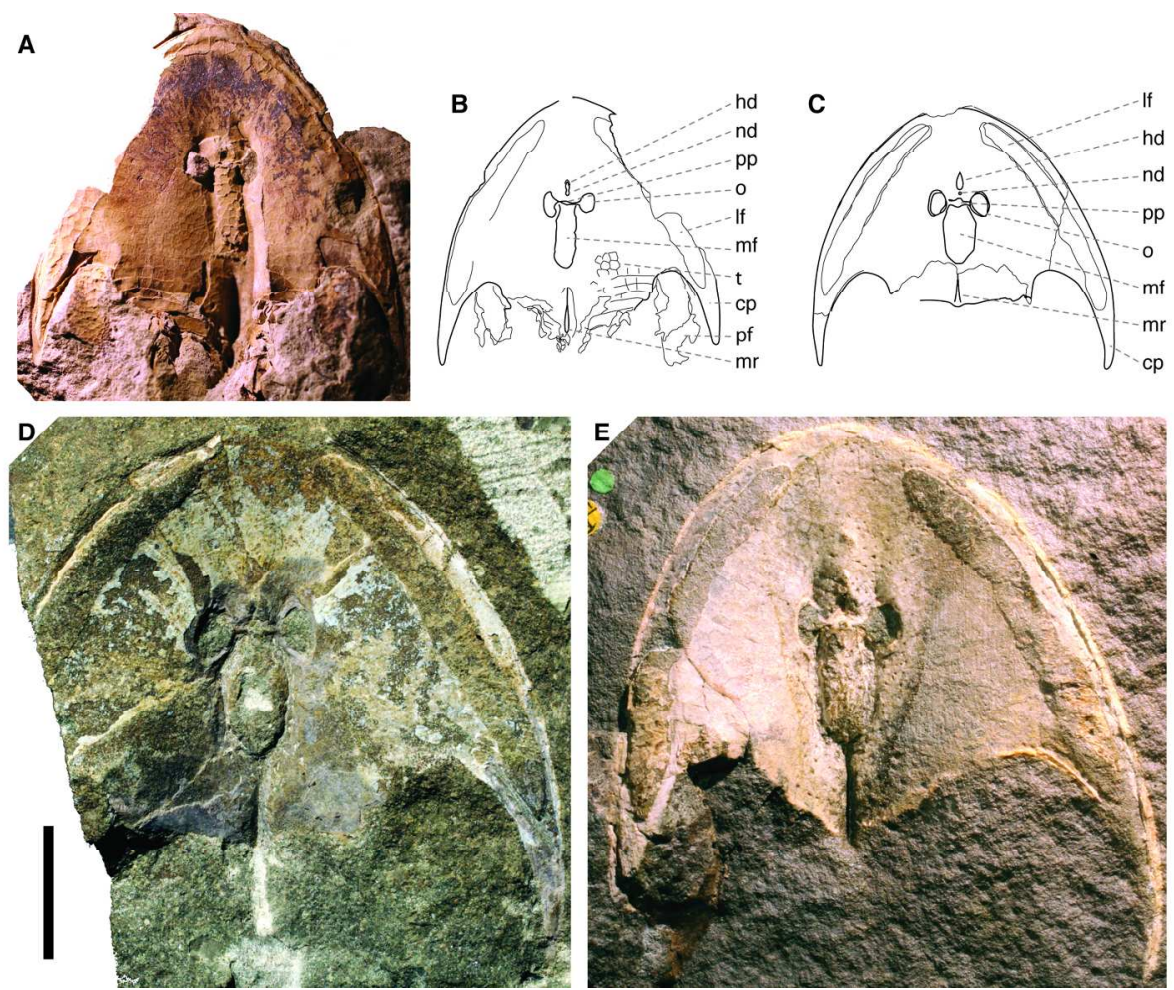

Janaspis newtonensis sp. nov. and Pattenaspis whitei. A. J. newtonensis NHM P17488; B. Interpretation of P17488; C. P. whitei, interpretation of P19198; D. P. whitei P19198; E. P. whitei P16310. To scale (20mm) except B, C. Abbreviations-as for figure 2. $182 \times 136 \mathrm{~mm}(300 \times 300$ DPI $)$ 

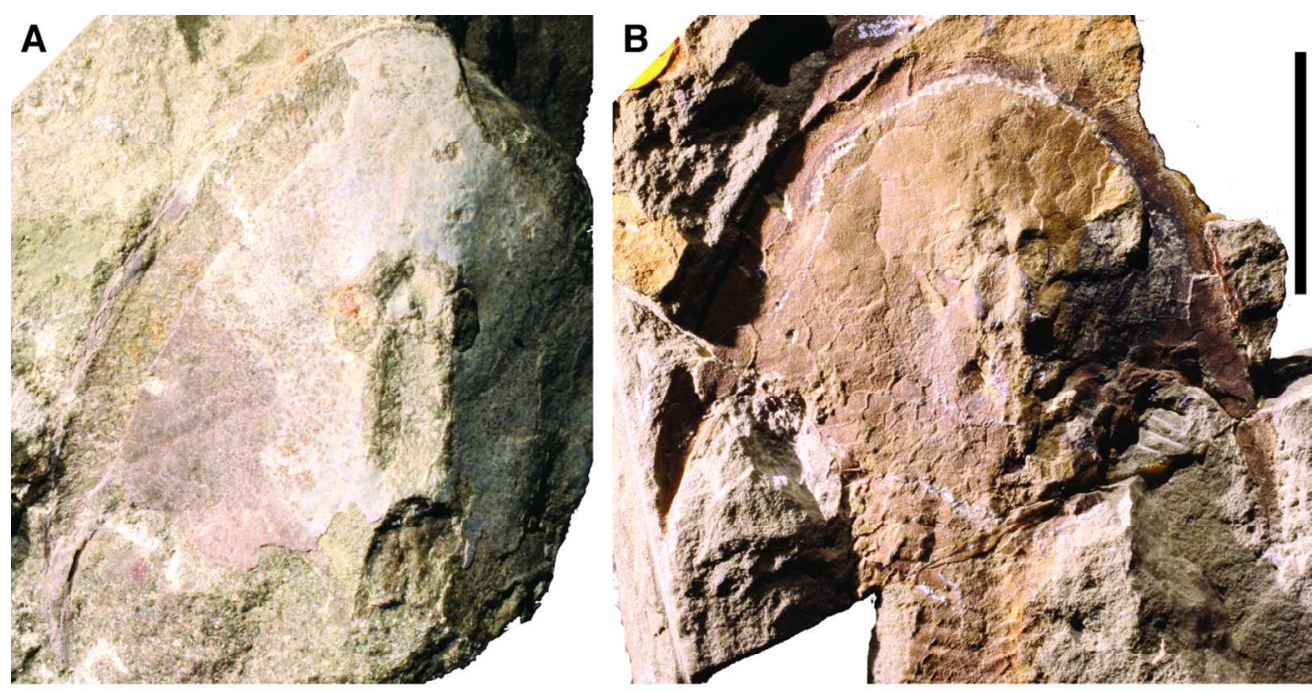

C

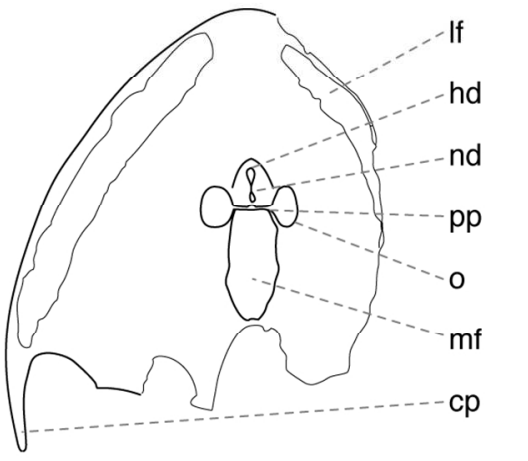

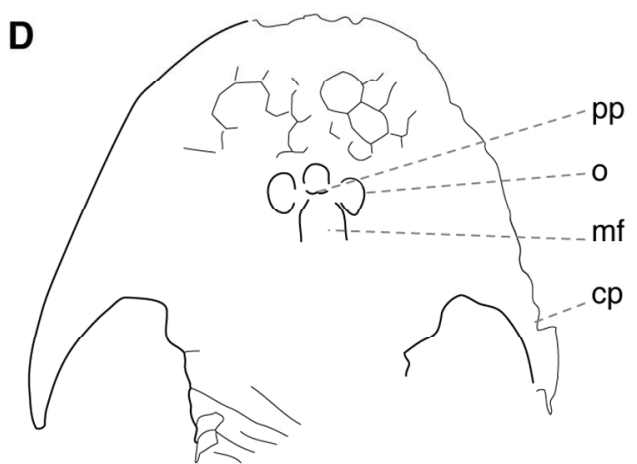

Cornuata gen. indet. sp. A and sp. B. A. sp. A NHM P19299; B. sp. B. P24922; C. Interpretation of P19299; D. Interpretation of PP24922. To scale $(20 \mathrm{~mm})$ except C, D. $122 \times 107 \mathrm{~mm}(300 \times 300 \mathrm{DPI})$ 


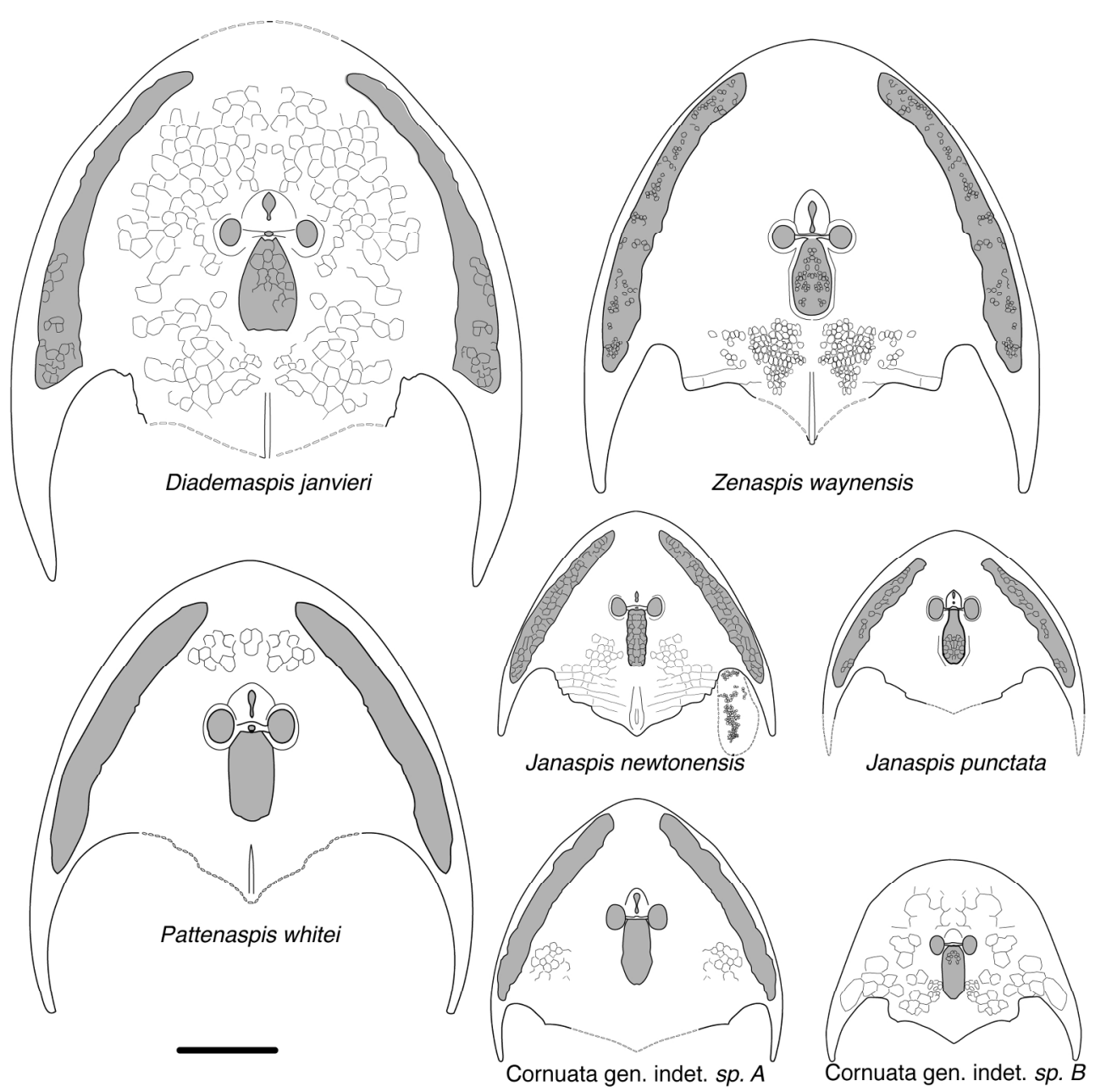

Reconstructions of the headshields of the Wayne Herbert osteostracan fauna. To scale (20mm). $182 \times 178 \mathrm{~mm}(300 \times 300 \mathrm{DPI})$ 


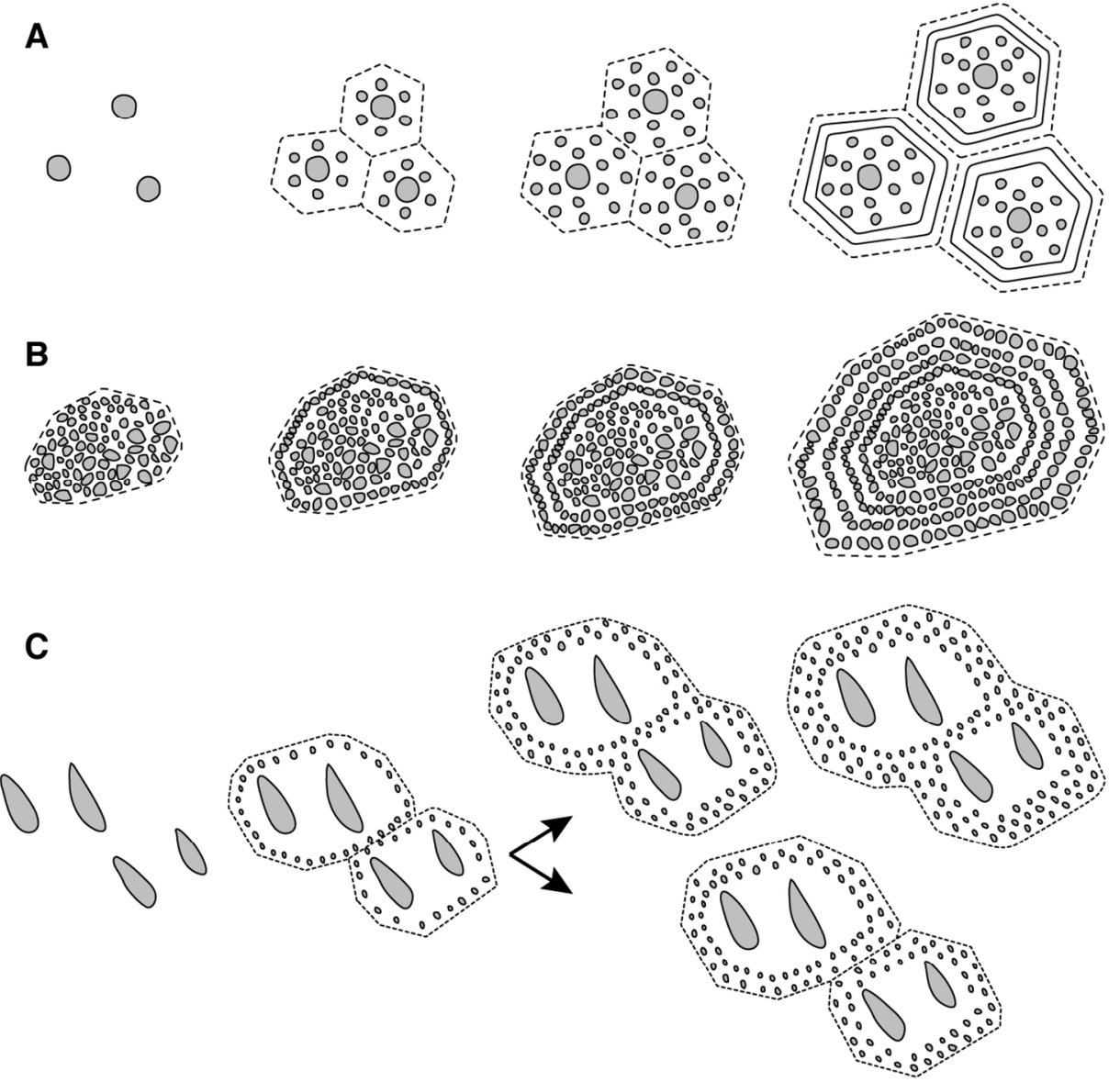

Growth stages of headshield tesserae of three osteostracan species: A. Superciliaspis gabrielsei reproduced from Hawthorn et al. (2008), with ossification of primordial tubercle followed by rings of tubercles and bones around; B. Cornuata gen. indet. sp. B, from simplest discernable unit of a tesserae plate with undifferentiated tubercles, followed by centrifugal addition of up to 30 tuberculated 'rings' of bone; C. Diademaspis janvieri sp. nov. from simplest discernable unit of individual large tubercles followed by fusion of up to 7 central tubercles surrounded by rings and then either individual tesserae fusing together by addition of tuberculated rings of bone enclosing the two separate units or growing as individual abutting units via marginal addition of tuberculated 'rings'. $122 \times 110 \mathrm{~mm}$ (300 x 300 DPI) 


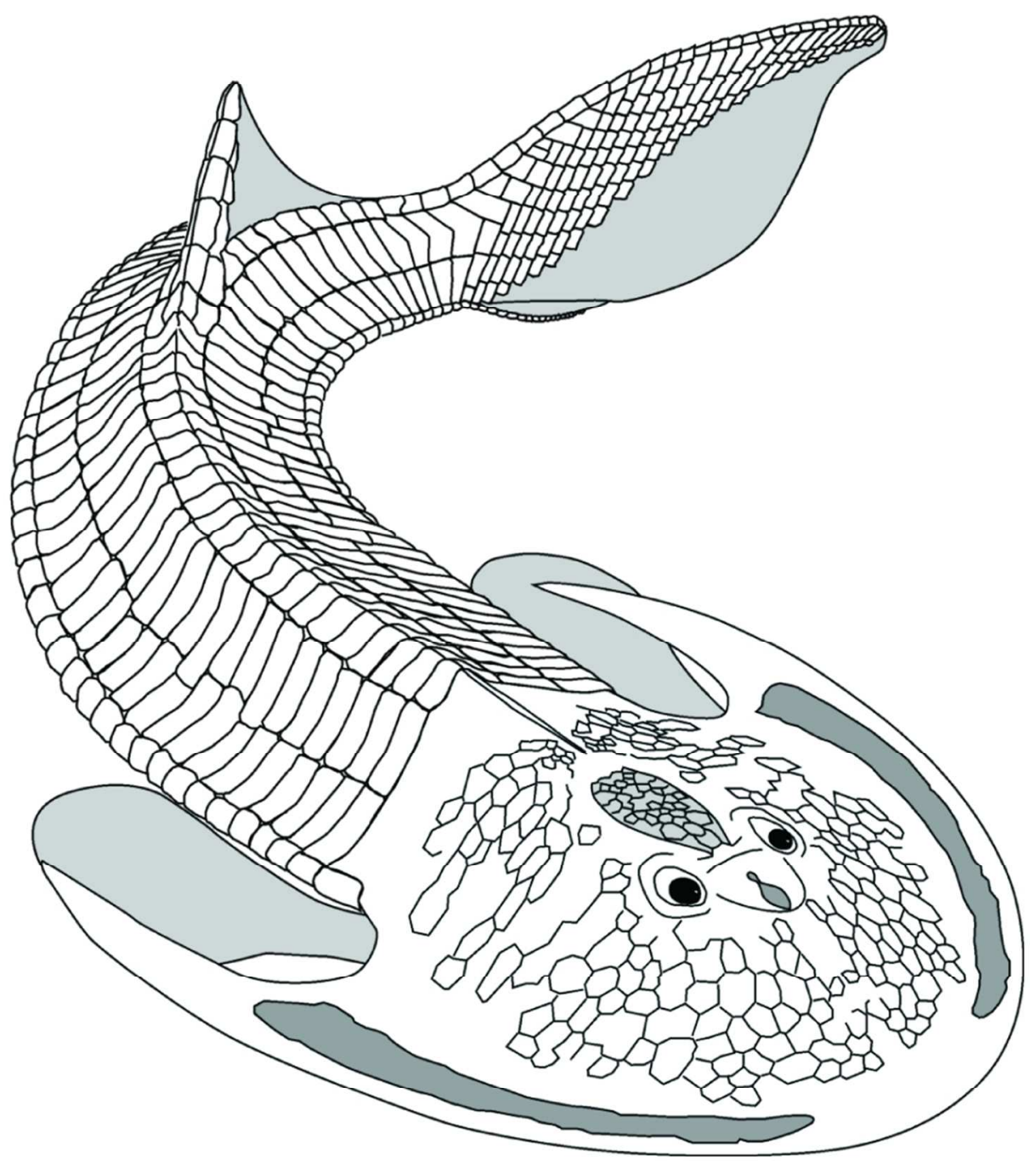

Reconstruction of Diademaspis janvieri sp. nov. 90x99mm (300 x 300 DPI) 
APPENDIX 1. Character suites defining morphogroups of the Wayne Herbert osteostracan fauna.

\begin{tabular}{|c|c|c|c|c|c|c|c|}
\hline & Morphogrol & and subsequen & t taxonomic as & signment & & & \\
\hline & $\begin{array}{l}\text { A } \\
\text { Zenaspis } \\
\text { waynensis } \\
\text { sp. nov. }\end{array}$ & $\begin{array}{l}\mathrm{B} \\
\text { Diademaspis } \\
\text { janvieri sp. } \\
\text { nov. }\end{array}$ & $\begin{array}{l}\mathrm{C} \\
\text { Janaspis } \\
\text { newtonensis } \\
\text { gen. et sp. } \\
\text { nov. }\end{array}$ & $\begin{array}{l}\text { D } \\
\text { Janaspis } \\
\text { punctata gen. } \\
\text { et sp. nov. }\end{array}$ & $\begin{array}{l}\mathrm{E} \\
\text { Pattenaspis } \\
\text { whitei }\end{array}$ & $\begin{array}{l}\text { F } \\
\text { Cornuata } \\
\text { gen. indet. } \\
\text { sp. A }\end{array}$ & $\begin{array}{l}\text { G } \\
\text { Cornuata } \\
\text { gen. indet. } \\
\text { sp. B }\end{array}$ \\
\hline $\begin{array}{l}\text { Shield midline } \\
\text { length/max } \\
\text { width }\end{array}$ & $92-95 \%$ & $96-100 \%$ & $82-87 \%$ & $70-76 \%$ & $67-78 \%$ & $>88 \%$ & $72 \%$ \\
\hline $\begin{array}{l}\text { Pre pineal } \\
\text { length }\end{array}$ & $49-51 \%$ & $50 \%$ & $42 \%$ & $42-45 \%$ & $47-48 \%$ & $>49 \%$ & $49 \%$ \\
\hline $\begin{array}{l}\text { Circumorbital } \\
\text { raised rims }\end{array}$ & Narrow & Thick & Narrow & Narrow & Narrow & Absent & Absent \\
\hline $\begin{array}{l}\text { Hypophysial } \\
\text { expansion }\end{array}$ & Present & Pronounced & Present & Present & Present & Present & Present \\
\hline $\begin{array}{l}\text { Median field } \\
\text { W/L }\end{array}$ & $59 \%$ & $58 \%$ & $36 \%$ & $37-45 \%$ & $40-59 \%$ & $48 \%$ & $?$ \\
\hline $\begin{array}{l}\text { Median field } \\
\text { shape }\end{array}$ & $\begin{array}{l}\text { Short and } \\
\text { broad, } \\
\text { tapering } \\
\text { anteriorly }\end{array}$ & $\begin{array}{l}\text { Short and } \\
\text { broad, } \\
\text { tapering } \\
\text { anteriorly for } \\
\text { much if its } \\
\text { length }\end{array}$ & $\begin{array}{l}\text { Elongate } \\
\text { with linear } \\
\text { straight } \\
\text { margins }\end{array}$ & $\begin{array}{l}\text { Narrow } \\
\text { anteriorly } \\
\text { broadening } \\
\text { posteriorly }\end{array}$ & $\begin{array}{l}\text { Long and } \\
\text { broad with } \\
\text { an octagonal } \\
\text { outline }\end{array}$ & $\begin{array}{l}\text { Long and } \\
\text { broad with } \\
\text { parallel } \\
\text { lateral } \\
\text { margins and } \\
\text { tapered } \\
\text { posterior }\end{array}$ & $?$ \\
\hline $\begin{array}{l}\text { Lateral field } \\
\text { shape }\end{array}$ & $\begin{array}{l}\text { Narrow, } \\
\text { broadening } \\
\text { posteriorly }\end{array}$ & $\begin{array}{l}\text { Narrow, } \\
\text { broadening } \\
\text { posteriorly }\end{array}$ & $\begin{array}{l}\text { Fairly broad, } \\
\text { anterior half } \\
\text { of field } \\
\text { tapers } \\
\text { anteriorly }\end{array}$ & $\begin{array}{l}\text { Broad, with } \\
\text { slightly } \\
\text { tapered } \\
\text { anterior } \\
\text { terminus }\end{array}$ & $\begin{array}{l}\text { Fairly broad } \\
\text { with pointed } \\
\text { posterior } \\
\text { margins }\end{array}$ & $\begin{array}{l}\text { Broad and } \\
\text { short }\end{array}$ & $?$ \\
\hline $\begin{array}{l}\text { Lateral Field } \\
\text { extent over } \\
\text { cornual } \\
\text { processes }\end{array}$ & $15 \%$ & $10 \%$ & $26 \%$ & $18-22 \%$ & $25-28 \%$ & $0 \%$ & $?$ \\
\hline $\begin{array}{l}\text { Cornual } \\
\text { process } \\
\text { length/max } \\
\text { shield length }\end{array}$ & $33 \%$ & $37 \%$ & $34 \%$ & $32-40 \%$ & $37-41 \%$ & $22 \%$ & $32 \%$ \\
\hline $\begin{array}{l}\text { Cornual } \\
\text { process shape }\end{array}$ & $\begin{array}{l}\text { Robust and } \\
\text { posteriorly } \\
\text { projected, }\end{array}$ & $\begin{array}{l}\text { Robust and } \\
\text { posteriorly } \\
\text { projected, }\end{array}$ & $\begin{array}{l}\text { Posterolatera } \\
\text { lly projected. } \\
\text { Maximum }\end{array}$ & $\begin{array}{l}\text { Posterolatera } \\
\text { lly projected } \\
\text { and curving }\end{array}$ & $\begin{array}{l}\text { Posterolatera } \\
\text { lly projected } \\
\text { and curving }\end{array}$ & $\begin{array}{l}\text { Gracile and } \\
\text { short }\end{array}$ & $\begin{array}{l}\text { Extremely } \\
\text { robust, } \\
\text { projecting }\end{array}$ \\
\hline
\end{tabular}




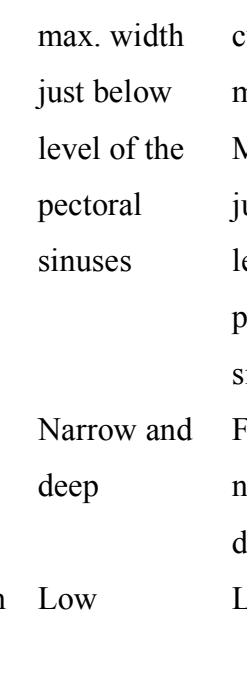

curving

width at tips medially. medially.

medially.

of cornual

Max length

Max length

measure mid measure mid

length of the length of the

cornual

cornual

processes.

processes.

sinuses

Pectoral sinus

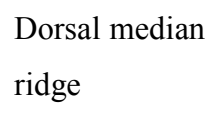

Dorsal median ridge

\section{Ornamentation}

of shield

Closely set

Low

minute

tesserae

tubercles

with granular tubercles

texture.

\section{forming a}

central island

surrounded

by 2-3 rows

of smaller

tubercles

Ornamentation

of ventral rim

$\begin{array}{ll}\text { Elongate } & \begin{array}{l}\text { Irregular } \\ \text { tubercles }\end{array} \\ \text { surrounded } & \begin{array}{l}\text { rows of } \\ \text { elongate }\end{array} \\ \text { by pitted } & \text { tubercles } \\ \text { borders, } & \text { approximatel } \\ \text { increasing in } & \text { y following } \\ \text { size } & \text { the shield } \\ \text { proximodista } & \text { margin } \\ \text { lly and } & \\ \text { arranged in } & \\ \text { up to 10 } & \\ \text { rows, slightly } \\ \text { discordant } \\ \text { with the } \\ \text { margin of the }\end{array}$

Up to 13

Broad and

deep

Broad and deep

\section{Broad and} deep

Broad and shallow

Prominent ?

dorsal

median spine

Tesserae

Tesserae of

exhibit a the

broad, low

headshield

Tessera

display 7-10

relief raised

covered by

large

rounded

centre

minute,

tubercles

closely set

surround a

by minute

tubercles

similar sized

which

- slightly

overprint 7-

10 large

larger central

obtuse and

evenly

spaced

tubercles

Up to 13

distinct

irregular

parallel rows rows of pits

of tiny pits

which

approximatel

$y$ follow the

margin of the

shield posterolateral

ly and

slightly

curving

medially at

their tips

Very broad

and deep

?

Tesserae

display up to

30 rows of

tubercles

surrounding

a granular

centre

Ornamentati

on similar to

the dorsal

shield. 
headshield

$\begin{array}{ll}1 & \text { headshield } \\ 2 & \end{array}$

4

5

6

7

8

9

10

11

12

13

14

15

16

17

18

19

20

21

22

23

24

25

26

27

28

29

30

31

32

33

34

35

36

37

38

39

40

41

42

43

44

45

46

47

48

49

50

51

52

53

54

55

56

57

58

59

60 


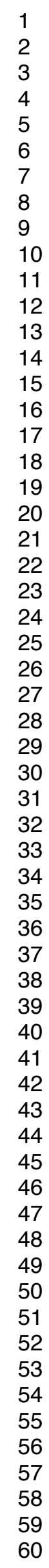

